Review

\title{
Status of Life Cycle Assessment (LCA) in Africa
}

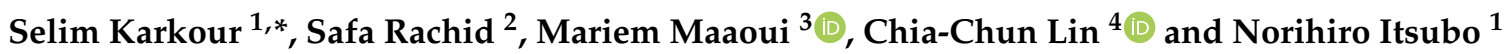 \\ 1 Graduate School of Environmental Studies, Tokyo City University, Tokyo 158-0087, Japan; itsubo-n@tcu.ac.jp \\ 2 Department of Health Sciences, Université Privée de Marrakech, Marrakech 42312, Morocco; \\ safarachid97@gmail.com \\ 3 Higher Institute of the Sciences and Techniques of Water of Gabes, University of Gabès, Gabes 6029, Tunisia; \\ meriem.maaoui@gmail.com \\ 4 Graduate Institute of Environmental Engineering, National Taiwan University, Taipei City 106032, Taiwan; \\ d03541009@ntu.edu.tw \\ * Correspondence: g1893103@tcu.ac.jp
}

check for

updates

Citation: Karkour, S.; Rachid, S.; Maaoui, M.; Lin, C.-C.; Itsubo, N. Status of Life Cycle Assessment (LCA) in Africa. Environments 2021, 8, 10. https://doi.org/10.3390/ environments 8020010

Academic Editor: Spyros Foteinis Received: 31 December 2020

Accepted: 31 January 2021

Published: 5 February 2021

Publisher's Note: MDPI stays neutral with regard to jurisdictional claims in published maps and institutional affiliations.

Copyright: (C) 2021 by the authors. Licensee MDPI, Basel, Switzerland. This article is an open access article distributed under the terms and conditions of the Creative Commons Attribution (CC BY) license (https:/ / creativecommons.org/licenses/by/ $4.0 /)$.

\begin{abstract}
Life cycle assessment (LCA) has received attention as a tool to evaluate the environmental impacts of products and services. In the last 20 years, research on the topic has increased, and now more than 25,000 articles are related to LCA in scientific journals databases such as the Scopus database; however, the concept is relatively new in Africa, where the number of networks has been highlighted to be very low when compared to the other regions. This paper focuses on a review of life cycle assessments conducted in Africa over the last 20 years. It aims at highlighting the current research gap for African LCA. A total of 199 papers were found for the whole continent; this number is lower than that for both Japan and Germany (more than 400 articles each) and nearly equal to developing countries such as Thailand. Agriculture is the sector which received the most attention, representing 53 articles, followed by electricity and energy (60 articles for the two sectors). South Africa (43), Egypt (23), and Tunisia (19) were the countries where most of the research was conducted. Even if the number of articles related to LCA have increased in recent years, many steps still remain. For example, establishing a specific life cycle inventory (LCI) database for African countries or a targeted ideal life cycle impact assessment (LCIA) method. Several African key sectors could also be assessed further.
\end{abstract}

Keywords: life cycle assessment; LCA; Africa; review

\section{Introduction}

According to United Nations (UN) projections, the African population, which is composed of more than 1.2 billion people at present, is expected to double by 2050 [1]. By this time, Nigeria, South Africa, and Egypt might also enter the list of the top 30 global economies by 2050 [2]. The high population and economic growth may have an impact on environmental problems in Africa. According to an Africa Environmental Outlook (AEO3) [3] report, several environmental problems already exist in Africa, including air pollution (more than one million people die every year in Africa due to air pollution [4]), water scarcity, and toxicity due to the heavy use of chemicals.

The economies of the 54 countries of Africa are mainly based on raw products [5,6] such as oil (Angola, Algeria, and Nigeria), metals (Egypt, Ghana, and South Africa), agrcultural products (cocoa beans in Cote d'Ivoire and Ghana), oilseeds (Ethiopia and Togo), or coffee (Ethiopia and Uganda).

As highlighted by Bjorn et al. (2013) [7], little has been done concerning life cycle assessment (LCA) in Africa, where networks/research groups are notably limited. LCA is a useful technique to assess the environmental impacts of a product or service throughout its entire life cycle, i.e., from the extraction of raw material through to processing, transport, use, and finally recycling/disposal [8]. By considering several different impacts over the entire life cycle, it is possible to identify potential tradeoffs from transitioning one stage 
to another or from one environmental problem to another. These are major differences with other assessment methods, such as the carbon/water footprint (focusing only on one environmental aspect) or the methods focusing only on the direct emissions of products during operation. Several global life cycle inventory databases [9] and life cycle impact assessment methods [10] exist that include African information, although the impact resolutions or data are limited.

Several country reviews have been conducted in recent years, such as in Austria [11], Brazil [12], Ghana, Ivory Coast, and Nigeria [13], Indonesia [14], Portugal [15], South Arica [16], and Sweden [17]. When focusing on the reviews published for African countries, it was found that several existing studies have been omitted, and several of the reported studies were not peer-reviewed and were sometimes ordered by private sector information. Additionally, key information has not been extracted (for example, the results or type of LCI database and the data used for the assessments). The existing research gaps for African countries are similar and it would be interesting to produce a clear overview of the situation for the whole continent.

Given this situation, we decided to focus on the current pub-lished studies in Africa while focusing on life cycle assessment in order to highlight what has been done so far, but also to identify possible research gaps. This review does not apply to African LCA researchers alone, but also to anyone who has a possible interest in conducting LCA rsearch in Africa.

\section{Materials and Methods}

This review was conducted with "Google Scholar" and "Scopus", research articles published between 2000 and 2020. Keywords for this review were "life cycle assessment", "life-cycle assessment", "LCA", and the name of each African country (e.g., "life cycle assessment" and "Morocco"). A total of 25,000 research articles were found when only using the keyword "life cycle assessment", while around 400 were found for African countries. As the focus was on environmental impacts, research based on other types of life cycle assessments such as life cycle costing (LCC) or social life cycle assessment (SCLA) were excluded. Research that was not peer-reviewed was also withdrawn to preserve the neutrality of the review. As the results found in the research articles were mainly based on life cycle inventory databases based on situations in developed countries (e.g., Ecoinent v2 [9]) or European life cycle assessment methods (e.g., CML-IA [18]), similar to previous reviews, we chose to not directly compare data from one region with data from another (i.e., Asia, Europe, or America). The LCIA results that were extracted from research articles are included in the Supplementary Materials.

\section{Results}

\subsection{Overview}

A total of 199 research articles related to African LCA were found.

Table A1 shows the Gross Domestic Product (GDP; Purchasing power parity (PPP), 2017 data) for each African country, as well as the main economic sector in each country and the number of published LCA studies. From Table A1 and Figure A1, it can be observed that the research published so far has not followed the economic situation in each country.

Africa's top economies (Egypt, Nigeria, South Africa, Algeria, and Morocco) are among the most active countries concerning LCA research. On the other hand, the least developed economies (Guinea-Bissau, Central African Republic, and Djibouti) do not even have a single research article focused on LCA. Surprisingly, some advanced African economies, such as Angola or Sudan, do not have a single research article either, despite the potential interesting research topics (oil and agricultural products for example). Mauritius's situation is singular, where, as a very active country with a relatively small GDP, Mauritius shows a good example for other African countries as the key drivers of the economy. Overall, North Africa has been the most active region, whereas many countries in Central Africa have not received any attention. South Africa is the leading country on the continent, 
with more than 40 LCA studies focused on the country. South Africa has the longest history with LCA research, starting from the beginning of the 2000s. Further recommendations concerning potential research topics in the future are provided in Section 4.3.

The number of research articles published from 2010 increased when compared with 2000-2010 (Figure 1), proving that LCA received more attention; however, it can be observed that publications in recent years (2017-2020), have not followed a constant pace. Therefore, the concept is still under development for the African continent, especially when considering that the number of LCA studies conducted by African research institutes/universities is still limited (The first author was based in Africa for 121 research articles).

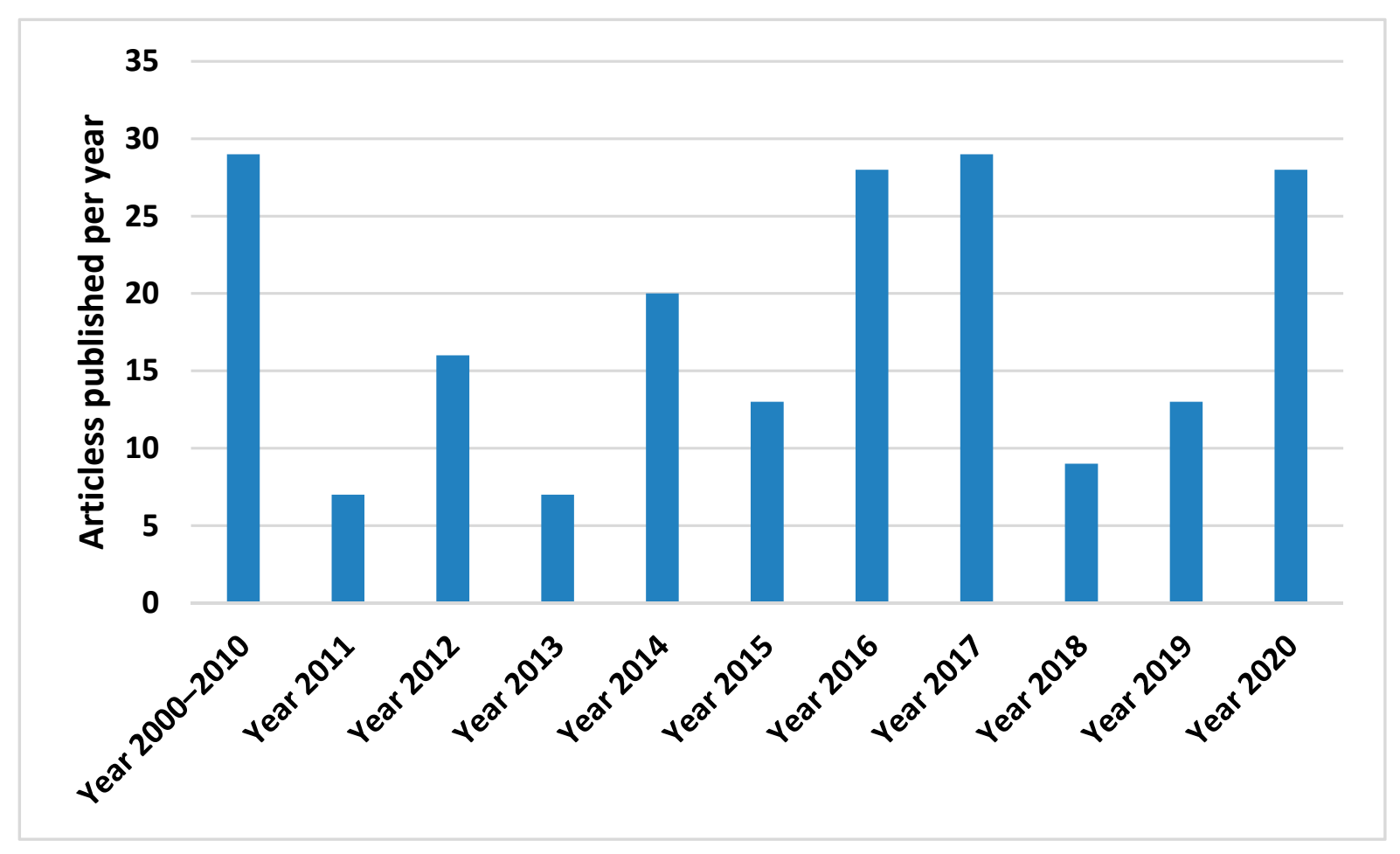

Figure 1. Research articles published by year.

When looking at which types of product/services have been studied the most (Figure 2), two topics received the most attention, namely, agriculture (53 articles) and energy / electricity (a total of 60 articles). This can be well understood, as many African countries rely on the agricultural sector for revenue (both from domestic consumption and overseas demand). For the electricity and energy sector, several problems exist in Africa due to solid fuel consumption in households, causing severe indoor air pollution [3]. The total electricity generation of Africa was around 800 TWh in 2020 [19] (which is nearly equal to the production of a developed country such as South Korea).

A description of each study is provided in Table 1. The main details of each research article are provided, such as the year of publication, country, product, functional unit, LCI database, and LCIA method used. In addition, Table A2 presents information such as the allocation, system boundaries, and institution of the first author for each study.

Concerning the life cycle inventory (LCI) database chosen, almost half of the research articles (100) used Ecoinvent as their LCI database, including 35 studies that used Ecoinvent v2 (mainly containing processes based on the situations in developed countries).

Concerning the Life-Cycle Impact Assessment (LCIA) method, CML was the most widely chosen (45) followed by ReCiPe (39), and EcoIndicator (24). It has to be noted that only nine studies chose ReCiPe2016 [10], one of the latest global LCIA methods, that contains characterization factors specific to African countries. 
A map of the research articles published per country is provided Figure 3. Additionally, a bar graph is presented in Figure 4, with the number of articles for the top eight most studied countries. It can be observed that these eight countries account for two thirds of the total number of African LCA publications. This highlights the fact that currently only $15 \%$ of Africa has been more or less covered whereas the environmental impacts of products or services in the $85 \%$ remaining countries remain mostly undetermined. It also shows the importance of the South African LCA community compared with most of the African countries.

When looking at the institution of the first author in each article, it was found that outside Africa, France (17), Spain (10), and the UK (10) were the three countries the most linked to the African LCA research. The information for each research article is presented in Table A2.

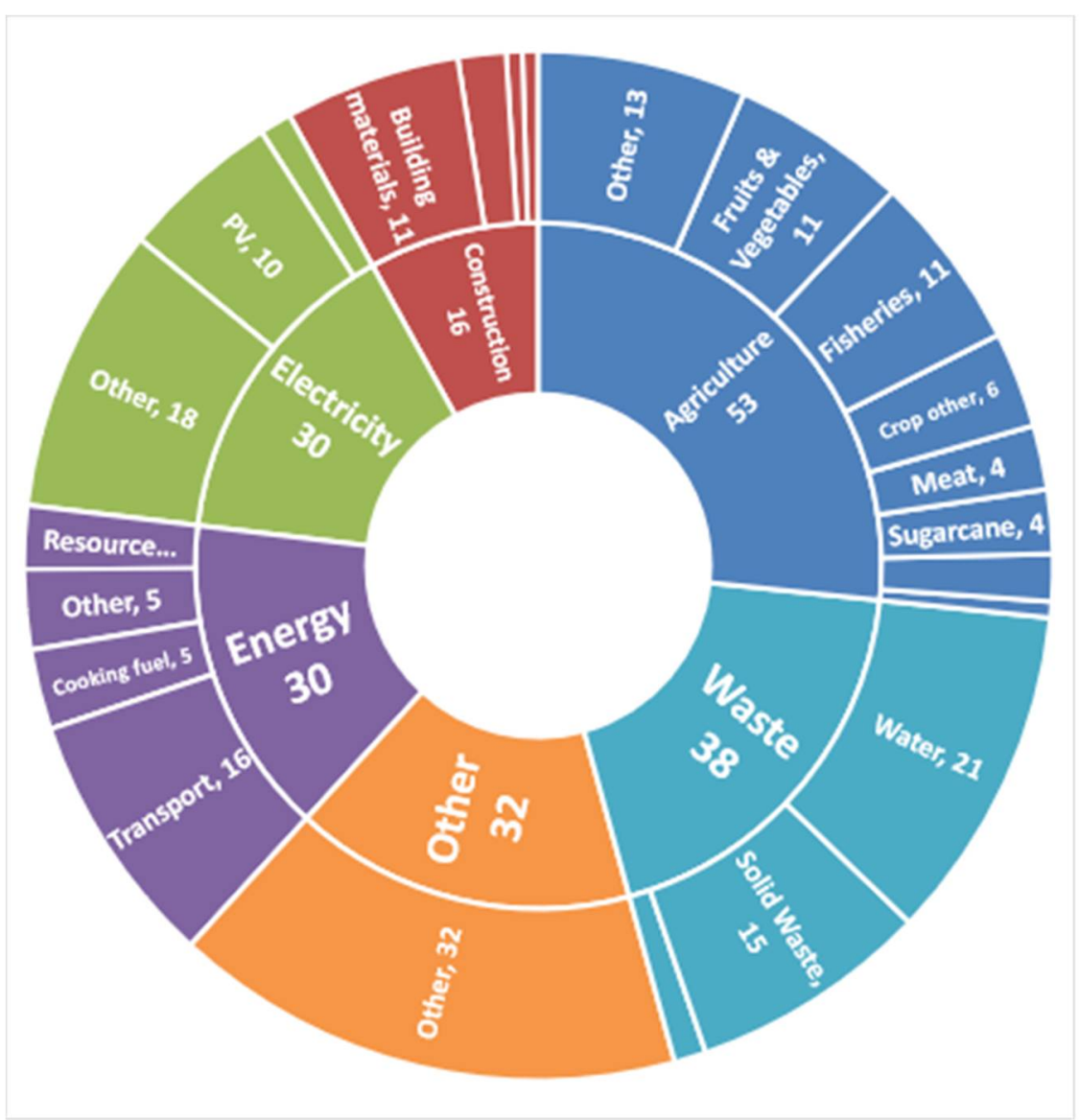

Figure 2. Research articles published by product type. 
Table 1. Summary of available life-cycle assessment (LCA) studies in Africa.

\begin{tabular}{|c|c|c|c|c|c|}
\hline Year & Country [Ref.] & Product & Functional Unit & LCI Database & LCIA Method \\
\hline 2011 & Algeria [20] & Drilling mud & 1 well drilled $4100 \mathrm{~m}$ deep & $\begin{array}{l}\text { Primary data/Existing } \\
\text { literature/SimaPro }\end{array}$ & IMPACT 2002+ \\
\hline 2012 & Algeria [21] & Recycled water & $\begin{array}{l}5 \mathrm{~L} \text { of recycled water intended to } \\
\text { be used for irrigation }\end{array}$ & $\begin{array}{c}\text { Primary data/Existing } \\
\text { literature/Ecoinvent }\end{array}$ & Eco-Indicator 95 \\
\hline 2013 & Algeria [22] & Potable water & $1 \mathrm{~L}$ of potable water & Primary data/SimaPro & Eco-Indicator 99 \\
\hline 2015 & Algeria [23] & Cement & 1 ton of cement & Primary data/SimaPro 7.1 & IMPACT 2000+ \\
\hline 2015 & Algeria [24] & Ammonia & $\begin{array}{c}1 \text { ton of anhydrous ammonia } \\
\text { with } 99.9 \% \text { purity }\end{array}$ & Primary data/GEMIS & Other \\
\hline 2016 & Algeria [25] & Drilling mud & Drilling mud treatment scenario & SimaPro 7 & Eco-Indicator 99 \\
\hline 2017 & Algeria [26] & Mussels & $\begin{array}{c}1 \text { ton of fresh Mediterranean } \\
\text { mussels }\end{array}$ & $\begin{array}{l}\text { Primary data/Existing } \\
\text { literature/Ecoinvent v3 }\end{array}$ & CML \\
\hline 2017 & Algeria [27] & Hotel building & impact/occupant $/ \mathrm{m}^{2}$ & Primary data/Ecoinvent & Other \\
\hline 2017 & Algeria [28] & Biodiesel & 1 ton of biodiesel & $\begin{array}{l}\text { Primary data/Existing } \\
\text { literature/Ecoinvent v3.1 }\end{array}$ & IMPACT 2002+ \\
\hline 2020 & Algeria [29] & PV Energy & 1 year of utilization & Primary data & Other \\
\hline 2014 & Benin [30] & Tomatoes & 1 hectare & Primary data & ILCD \\
\hline 2016 & Burkina Faso [32] & $\begin{array}{l}\text { Energy sources for a water } \\
\text { purification plant }\end{array}$ & One year & Ecoinvent v3 & ReCiPe \\
\hline 2018 & Burkina Faso [33] & Jatropha biofuel & $\begin{array}{c}\text { hectare.year/gigajoule of J. curcas } \\
\text { SVO or JME }\end{array}$ & Primary data/Existing literature & ReCiPe \\
\hline 2018 & Burkina Faso [34] & PV & $1 \mathrm{~L}$ of oil & Ecoinvent & ReCiPe World E/A \\
\hline 2010 & Cameroon [35] & Palm Oil & $1 \mathrm{MJ}$ in a car engine & $\begin{array}{l}\text { Primary data/Existing } \\
\text { literature/LCA database }\end{array}$ & Other \\
\hline 2010 & Cameroon [36] & Road & $\begin{array}{c}\text { Number of vehicles moving on } \\
\text { that road for a period of fifty } \\
\text { years }\end{array}$ & Primary data/Existing literature & Other \\
\hline
\end{tabular}


Table 1. Cont.

\begin{tabular}{|c|c|c|c|c|c|}
\hline Year & Country [Ref.] & Product & Functional Unit & LCI Database & LCIA Method \\
\hline 2012 & Cameroon [37] & Farms & $\begin{array}{l}1 \text { ton of fresh fish (both tilapia } \\
\text { and African catfish) at the farm } \\
\text { exit gate }\end{array}$ & Existing literature/Ecoinvent & CML2001 \\
\hline 2019 & Cameroon [39] & Jatropha & $1 \mathrm{MJ}$ of JVO obtained & $\begin{array}{c}\text { Primary data/Existing } \\
\text { literature/Ecoinvent v2 }\end{array}$ & Other \\
\hline 2010 & Egypt [40] & Wastewater & Treatment of $1 \mathrm{~m}^{3}$ of wastewater & Primary data/Existing literature & Eco-Indicator 99 \\
\hline 2012 & Egypt [41] & Wastewater & Treatment of $1 \mathrm{~m}^{3}$ of wastewater & Existing literature & Eco-Indicator 99 \\
\hline 2014 & Egypt [42] & Building materials (Method) & - & - & - \\
\hline 2014 & Egypt [43] & Residential building & 1 usable floor space $\left(\mathrm{m}^{2}\right)$ & $\begin{array}{l}\text { Primary data/Existing } \\
\text { literature/Ecoinvent V3 }\end{array}$ & IMPACT 2002+ \\
\hline 2014 & Egypt [44] & Building database & - & - & - \\
\hline 2014 & Egypt [45] & Cotton & $1 \mathrm{~kg}$ of dyed cotton yarn & Primary data/Ecoinvent v2 & Eco-Indicator 99 \\
\hline 2015 & Egypt [46] & Diesel fuel, solar pump & Irrigation of 1 feddan of rice & Primary data & IMPACT 2002+ \\
\hline 2015 & Egypt [47] & Jatropha Biodiesel & 1 ton of Jatropha Biodiesel & Primary data & IMPACT 2002+ \\
\hline 2016 & Egypt [49] & Energy system & $\begin{array}{l}\text { The operation of the power } \\
\text { supply system for a calendar year }\end{array}$ & Existing literature/ecoinvent & Eco-Indicator 99 \\
\hline 2016 & Egypt [50] & Aquaculture & $\begin{array}{l}1 \text { ton of live tilapia at the } \\
\text { farm gate }\end{array}$ & $\begin{array}{l}\text { Primary data/Existing } \\
\text { literature/Ecoinvent v2.2 }\end{array}$ & Other \\
\hline 2016 & Egypt [51] & LCA tool & - & - & - \\
\hline 2016 & Egypt [52] & Transport vehicles & $\begin{array}{l}\text { Total Vehicle Kilometers } \\
\text { Travelled (VKT) in Egypt }\end{array}$ & Primary data?/Existing literature & IMPACT 2002+ \\
\hline 2016 & Egypt [53] & Tilapia & 1 ton of Tilapia & $\begin{array}{l}\text { Primary data/Existing } \\
\text { literature/Ecoinvent v2 }\end{array}$ & CML baseline 2000 \\
\hline 2016 & Egypt [54] & Acrylic fiber & $1 \mathrm{~kg}$ production of acrylic fiber. & $\begin{array}{l}\text { Primary data/Existing } \\
\text { literature/Ecoinvent v2.2 }\end{array}$ & Eco-Indicator 99 \\
\hline
\end{tabular}


Table 1. Cont.

\begin{tabular}{|c|c|c|c|c|c|}
\hline Year & Country [Ref.] & Product & Functional Unit & LCI Database & LCIA Method \\
\hline 2016 & Egypt [55] & Cement & $1 \mathrm{~kg}$ of cement & Primary data/Ecoinvent v3 & IMPACT 2002+ \\
\hline 2016 & Egypt [56] & Acrylic fiber & $\begin{array}{l}1000 \text { kg production of } \\
\text { acrylic fiber. }\end{array}$ & Primary data/Ecoinvent v2 & Eco-Indicator 99 \\
\hline 2017 & Egypt [58] & Lubrication oil & $1000 \mathrm{~kg}$ lubrication used oil & Existing literature/Ecoinvent v2 & Eco-Indicator 99 \\
\hline 2019 & Egypt [59] & Waste water & $1 \mathrm{~m}^{3}$ of treated wastewater & $\begin{array}{l}\text { Primary data/Existing } \\
\text { literature/Ecoinvent v2 }\end{array}$ & CML2000 \\
\hline 2020 & Egypt [60] & Waste & 1 ton of waste & Primary data & Other \\
\hline 2020 & Egypt [61] & Wastewater & $1 \mathrm{~m}^{3}$ of treated wastewater & Primary data/Gabi & ReCiPe \\
\hline 2020 & Egypt [62] & Bioethanol & 1 ton of bioethanol & $\begin{array}{l}\text { Primary data/Existing } \\
\text { literature/Ecoinvent v3 }\end{array}$ & CML-IA \\
\hline 2012 & Ethiopia [63] & Rose cultivation & $\begin{array}{c}1 \text { bunch of roses consisting of } \\
20 \text { stems }\end{array}$ & Ecoinvent v2 & CML 2 baseline 2000 \\
\hline 2017 & Ethiopia [64] & Biogas, dung & $\begin{array}{l}\text { Amount of primary energy } \\
\text { needed to provide energy carriers }\end{array}$ & $\begin{array}{l}\text { Primary data/Existing } \\
\text { literature/ecoinvent v2.2 }\end{array}$ & CML2001 \\
\hline 2020 & Ethiopia [66] & Electricity from a wind farm & $\begin{array}{l}\text { The generation of } 1 \mathrm{kWh} \text { of } \\
\text { average electricity }\end{array}$ & $\begin{array}{l}\text { Primary data/Existing } \\
\text { literature/Ecoinvent v3 }\end{array}$ & ReCiPe 2008 \\
\hline 2012 & Ghana [67] & Cooking fuels & $\begin{array}{l}1 \mathrm{MJ} \text { of energy delivered to the } \\
\text { cooking pot }\end{array}$ & Primary data/Ecoinvent/Gabi 4 & CML2001 \\
\hline 2020 & Ghana [68] & Building & $\begin{array}{l}180.50 \mathrm{~m}^{2} \text { gross floor area (GFA) } \\
\text { for a lifespan of } 50 \text { years }\end{array}$ & Primary data/ICE & Other \\
\hline 2020 & Ghana [69] & Food products & $1 \mathrm{~kg}$ of product $/ 1 \mathrm{kcal}$ unit & $\begin{array}{l}\text { Existing } \\
\text { literature/Ecoinvent v3.5 }\end{array}$ & CML2001/ReCiPe2008 \\
\hline 2011 & Ghana [70] & Timber & $\begin{array}{c}1 \mathrm{~kg} / 1 \text { euro } / 1 \mathrm{~m}^{3} \text { of product } \\
\text { produced }\end{array}$ & Existing literature & CML2000 \\
\hline 2011 & Ghana [71] & Biogas & $\begin{array}{l}\text { Production of } 1 \mathrm{MJ} \text { of } \\
\text { useful energy }\end{array}$ & Primary data/Ecoinvent/Gabi 4 & CML2001 \\
\hline 2011 & Ghana [72] & Cyanide containers & 1 package & Primary data/Existing literature & Eco-Indicator 99 \\
\hline
\end{tabular}


Table 1. Cont.

\begin{tabular}{|c|c|c|c|c|c|}
\hline Year & Country [Ref.] & Product & Functional Unit & LCI Database & LCIA Method \\
\hline 2010 & Ghana [73] & Timber & $1 \mathrm{~m}^{3} / 1 \mathrm{~kg} / 1$ euro & Primary data & Other \\
\hline 2008 & Ghana [74] & Cocoa & $1 \mathrm{~kg}$ of cocoa beans processed & Primary data/Ecoinvent/Gabi 4 & CML2001 \\
\hline 2009 & Ivory Coast [75] & Biofuel & $1 \mathrm{MJ}$ of JME & Primary data/Ecoinvent & Other \\
\hline 2007 & Kenya [76] & Food products & 1 ton of grade 1 product & Existing literature/Ecoinvent & CML baseline 2000 \\
\hline 2016 & Kenya [77] & Biowaste & $1 \mathrm{~kg}$ of wet biowaste & $\begin{array}{l}\text { Primary data/Existing } \\
\text { literature/Ecoinvent v3.3 }\end{array}$ & ReCiPe 2016 \\
\hline 2017 & Kenya [78] & $\begin{array}{l}\text { Solar photovoltaic } \\
\text { microgrid system }\end{array}$ & $\begin{array}{l}1 \mathrm{kWh} \text { of electricity consumed by } \\
\text { the community }\end{array}$ & Ecoinvent v2.2/Gabi 6 & ReCiPe 2008 \\
\hline 2020 & Kenya [79] & Food products & $1 \mathrm{~kg}$ of edible boneless weight & Existing literature & IPCC/AWARE \\
\hline 2020 & Kenya [80] & Bioenergy & Different scenarios & $\begin{array}{l}\text { Existing literature/Ecoinvent } \\
\text { v3.1/Agrifootprint }\end{array}$ & ReCiPe2016 \\
\hline 2014 & Libya [81] & Crude oil & $\begin{array}{l}\text { Ultimately presented in terms of } \\
\text { the functional unit }(\mathrm{km})\end{array}$ & Primary data/Ecoinvent & Eco-Indicator 99 \\
\hline 2015 & Libya [82] & Wind farm & $1 \mathrm{kWh}$ of electricity produced & Primary data & Other \\
\hline 2014 & Madagascar [83] & Solar cooker & 1 meal & Primary data & Other \\
\hline 2017 & Madagascar [84] & Electricity generation & 1 year & Primary data/GEMIS & Other \\
\hline 2016 & Malawi [86] & Building materials & $1 \mathrm{~m}^{2}$ wall & Primary data/Existing literature & Other \\
\hline 2019 & Malawi [87] & Mining products & $1 \mathrm{~kg}$ of rare earth oxide (REO) & $\begin{array}{l}\text { Primary data/Existing } \\
\text { literature/Ecoinvent v3/Gabi }\end{array}$ & TRACI \\
\hline 2004 & Mali [88] & Thermosyphon solar water & $\begin{array}{l}1 \text { complete solar hot } \\
\text { water system }\end{array}$ & Primary data/Existing literature & Other \\
\hline 2014 & Mali [89] & Jatropha-based bioenergy & $1 \mathrm{MJ}$ of electricity. & Primary data/Ecoinvent v2.2 & ReCiPe \\
\hline 2017 & Mali [90] & Insect-based feed production & $\begin{array}{c}1 \mathrm{~kg} \text { whole dried larvae with a } \\
\text { residual water content of less } \\
\text { than } 10 \%\end{array}$ & $\begin{array}{c}\text { Existing } \\
\text { literature/Ecoinvent v3.0 }\end{array}$ & Other \\
\hline 2017 & Mali [91] & Shea butter & $1 \mathrm{~kg}$ of shea butter & Primary data/Existing literature & CML 2001 \\
\hline 2020 & Mali [92] & Cotton & $\begin{array}{c}1 \mathrm{t} \text { and } 1 \text { ha of seed cotton at the } \\
\text { farm gate and } 1 \mathrm{t} \text { and } 1 \text { ha } \\
\text { equivalent of baled cotton fiber } \\
\text { and cottonseed at the ginning } \\
\text { plant gate }\end{array}$ & $\begin{array}{l}\text { Primary data/Ecoinvent } \\
\text { v3/World Food LCA Database }\end{array}$ & ILCD \\
\hline
\end{tabular}


Table 1. Cont.

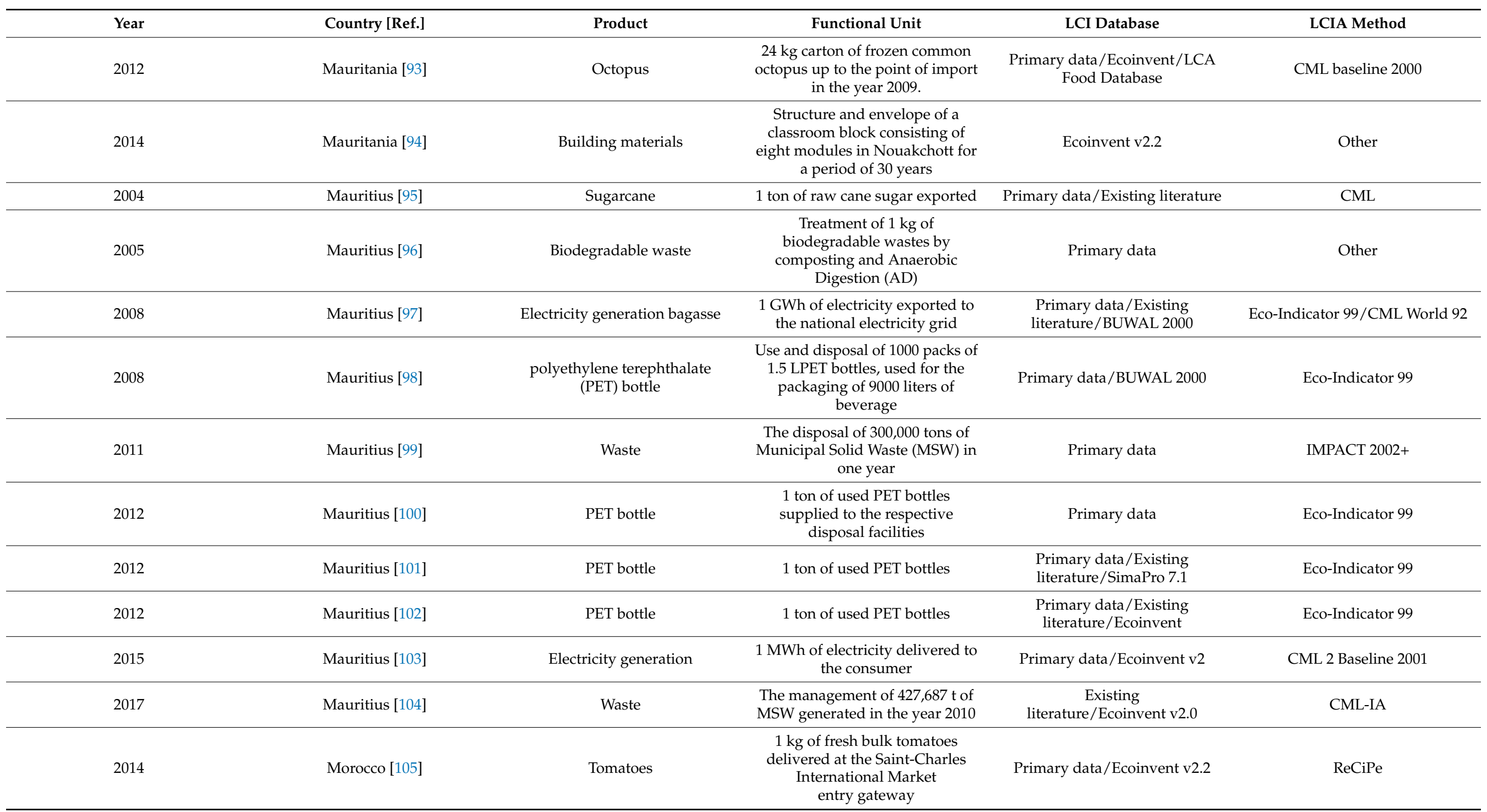


Table 1. Cont.

\begin{tabular}{|c|c|c|c|c|c|}
\hline Year & Country [Ref.] & Product & Functional Unit & LCI Database & LCIA Method \\
\hline 2014 & Morocco [106] & Perennial crops & $1 \mathrm{~kg}$ of fresh fruits & Primary data/Ecoinvent v2.2 & ReCiPe 2008 \\
\hline 2016 & Morocco [107] & Clementines & $1 \mathrm{~kg}$ raw fruit at the farm gate & Ecoinvent v2.2 & ReCiPe \\
\hline 2016 & Morocco [108] & Photovoltaic power plant & $1 \mathrm{MWh}$ & Ecoinvent v3 & ReCiPe \\
\hline 2016 & Morocco [109] & Photovoltaic power plant & $1 \mathrm{MW}$ & Ecoinvent v2.2 & Other \\
\hline 2016 & Morocco [110] & Fresh fruit & $1 \mathrm{~kg}$ of fresh fruits & Primary data/Ecoinvent v2.2 & ReCiPe 2008 \\
\hline 2018 & Morocco [111] & Electric energy & $\begin{array}{c}1 \mathrm{kWh} \text { of produced electric } \\
\text { energy }\end{array}$ & $\begin{array}{c}\text { Primary data/Gabi/Ecoinvent } \\
\text { v3.1 }\end{array}$ & CML2001 \\
\hline 2019 & Morocco [112] & Automotive headrest & 1 headrest for automotive seating & Primary data/Ecoinvent & IMPACT 2002+ \\
\hline 2020 & Morocco [113] & $\begin{array}{l}\text { hybrid solar/biomass } \\
\text { micro-cogeneration }\end{array}$ & $1 \mathrm{kWh}$ of electricity & Primary data/WIOD/EORA & ILCD \\
\hline 2020 & Morocco [114] & Solar water heater & Utilization during one year & Primary data & Other \\
\hline 2020 & Morocco [115] & Waste Water & $\begin{array}{l}\text { Treat effluent of one population } \\
\text { equivalent for one day }\end{array}$ & Primary data & ReCiPe midpoint 2014 \\
\hline 2013 & Mozambique [116] & Jatropha oil & $\begin{array}{l}1 \mathrm{MJ} \text { of energy in the form of } \\
\text { jatropha oil or fossil diesel }\end{array}$ & Primary data/Existing literature & Other \\
\hline 2010 & Nigeria [118] & Future electricity scenarios & $\begin{array}{l}56,160 \mathrm{TJ} / \mathrm{yr} \text { for } 2003 ; 346,000 \\
\mathrm{TJ} / \mathrm{yr} \text { for } 2010 ; 551,000 \mathrm{TJ} / \mathrm{yr} \text { for } \\
2020 ; 764,000 \mathrm{TJ} / \mathrm{yr} \text { for } 2030\end{array}$ & $\begin{array}{l}\text { Primary data/Existing } \\
\text { literature/GEMIS 4.3/SimaPro }\end{array}$ & Other \\
\hline 2014 & Nigeria [119] & Biodigesters & One meal & $\mathrm{x}$ & Other \\
\hline 2015 & Nigeria [120] & Residential building & One life-cycle & Primary data & Other \\
\hline 2015 & Nigeria [121] & $\begin{array}{l}\text { Municipal solid waste } \\
\text { management }\end{array}$ & Waste Management scenarios & Primary data/Ecoinvent & Other \\
\hline 2015 & Nigeria [122] & Jatropha biofuel & $\begin{array}{c}1 \mathrm{MJ} \text { of fuel used in a typical } \\
\text { biodiesel-fired power } \\
\text { plant/Jatropha plantation of } 1 \\
\text { hectare (ha) over a 20-year period }\end{array}$ & $\begin{array}{c}\text { Literature re- } \\
\text { view/Agrifootprint/Ecoinvent }\end{array}$ & ReCiPe \\
\hline 2016 & Nigeria [123] & Shea butter & $1 \mathrm{~kg}$ of shea butter & Primary data/Ecoinvent & TRACI \\
\hline
\end{tabular}


Table 1. Cont.

\begin{tabular}{|c|c|c|c|c|c|}
\hline Year & Country [Ref.] & Product & Functional Unit & LCI Database & LCIA Method \\
\hline 2019 & Nigeria [124] & Electricity & $1 \mathrm{kWh}$ of electricity generation & Existing literature/Gabi & CML 2001 \\
\hline 2020 & Nigeria [125] & Electricity & $\begin{array}{l}1 \mathrm{MWh} \text { of net electricity } \\
\text { produced }\end{array}$ & Primary data/Ecoinvent & CML 2001 \\
\hline 2020 & Nigeria [127] & Cassava & 1 ha land area & Primary data/Existing literature & Other \\
\hline 2020 & Nigeria [128] & Sweet Oranges & 1 ha & Primary data & Other \\
\hline 2013 & Nigeria [129] & Passenger transport & $\begin{array}{c}467 \text { billion people } / \mathrm{km} \text { in } \\
2003 / 721 \text { billion people } / \mathrm{km} \text { in } \\
2020 / 942 \text { billion people } / \mathrm{km} \\
\text { in } 2030\end{array}$ & Existing literature/GEMIS4.3 & CML 2001 \\
\hline 2013 & Nigeria [130] & Biodiesel & $\begin{array}{l}\text { The functional unit was defined } \\
\text { as one kilogram of soybean }\end{array}$ & Primary data/Existing literature & Other \\
\hline 2017 & Nigeria, Ghana, ivory coast [13] & Review & - & - & - \\
\hline 2019 & Rwanda [131] & Tomatoes & $1 \mathrm{~kg}$ of tomatoes at farm-gate & $\begin{array}{c}\text { Existing } \\
\text { literature/Ecoinvent v2.2 }\end{array}$ & ILCD \\
\hline 2011 & Senegal [132] & Shrimp products & $\begin{array}{c}1 \mathrm{~kg} \text { of shrimp and the } \\
\text { accompanying packaging } \\
\text { material at the point of import to } \\
\text { Europe }\end{array}$ & $\begin{array}{l}\text { Primary data/Existing } \\
\text { literature/Ecoinvent v2 }\end{array}$ & CML 2002 \\
\hline 2019 & Somalia [133] & Treated water & $1 \mathrm{~L}$ of treated water & $\begin{array}{l}\text { Existing } \\
\text { literature/Ecoinvent v3.4 }\end{array}$ & ReCiPe 2008 \\
\hline 2002 & South Africa [134] & Review & - & - & Review \\
\hline 2002 & South Africa [135] & Wool & $1 \mathrm{~kg}$ of dyed two-fold wool yarn & Primary data/Existing literature & Method \\
\hline 2002 & South Africa [136] & Potable water & $1 \mathrm{~kL}$ of potable water & Primary data/Gabi 3 & ReCiPe \\
\hline 2003 & South Africa [137] & Method & - & - & - \\
\hline 2006 & South Africa [138] & Water supply & $\begin{array}{l}1 \mathrm{M} \ell / \mathrm{d} \text { of potable water } \\
\text { supplied at Rosslyn }\end{array}$ & Primary data & special African \\
\hline 2009 & South Africa [139] & Urban water & $1 \mathrm{~kL}$ of water & $\begin{array}{c}\text { Primary data/Existing } \\
\text { literature/Gabi } 3\end{array}$ & CML \\
\hline 2010 & South Africa [140] & Sugar & 1 ton of raw sugar & Primary data/Ecoinvent & Eco-Indicator 99 \\
\hline 2012 & South Africa [141] & Photovoltaic/Wind Radio & $\begin{array}{c}\text { One radio base station utilization } \\
\text { during } 10 \text { years }\end{array}$ & Primary data & ReCiPe2008 \\
\hline 2014 & South Africa [142] & Container glass waste & 1 ton of container glass waste & Primary data/Ecoinvent v2 & Other \\
\hline
\end{tabular}


Table 1. Cont.

\begin{tabular}{|c|c|c|c|c|c|}
\hline Year & Country [Ref.] & Product & Functional Unit & LCI Database & LCIA Method \\
\hline 2014 & South Africa [143] & Clay brick Walling & 1 standard brick equivalent (SBE) & Primary data/Ecoinvent v2.2 & IMPACT 2002+ \\
\hline 2014 & South Africa [144] & Polymer bag & $1 \mathrm{~m}^{2}$ of plastic film & Primary data/Ecoinvent v2.2 & IMPACT 2002+ \\
\hline 2015 & South Africa [145] & Biofuel & $1 \mathrm{~km}$ traveled & $\begin{array}{l}\text { Aspen simulation/Existing litera- } \\
\text { ture/Ecoinvent v2.2/Greet } 2.7\end{array}$ & Other \\
\hline 2016 & South Africa [146] & Agriculture & $\begin{array}{l}1 \text { metric ton of extractable } \\
\text { sucrose delivered at the mill gate } \\
\text { in the form of sugarcane stems } \\
\text { or billets. }\end{array}$ & $\begin{array}{l}\text { Primary data/Existing } \\
\text { literature/Greet }\end{array}$ & Other \\
\hline 2016 & South Africa [147] & Method for constructing LCAs & - & - & - \\
\hline 2016 & South Africa [148] & Books & $\begin{array}{l}\text { The reading of } 21 \text { books by a } \\
\text { single user in two hours per day } \\
\text { over a four-year period }\end{array}$ & Ecoinvent v3 & ReCiPe2008 \\
\hline 2016 & South Africa [149] & Lignocellulosic lactic acid & $\begin{array}{l}1 \text { ton of Lactic Acid } \\
\text { (LA) produced }\end{array}$ & Aspen/Ecoinvent & ReCiPe \\
\hline 2017 & South Africa [150] & Timber & $\begin{array}{c}\text { Quantity of materials required to } \\
\text { construct the roof truss system of } \\
\text { a house }\end{array}$ & AUSLCI/Ecoinvent v3.1 & ReCiPe \\
\hline 2017 & South Africa [152] & Meat & $1 \mathrm{~kg}$ of LW meat $/ 1 \mathrm{~kg}$ of CW meat & Primary data/Ecoinvent & CML IA \\
\hline 2017 & South Africa [153] & Biorefineries & $\begin{array}{l}\text { a biorefinery with a processing } \\
\text { capacity of } 65(\mathrm{tDM} / \mathrm{h}) \text { tons } \\
\text { bagasse and trash per hour }\end{array}$ & Primary data/Existing literature & Eco-Indicator 99 \\
\hline 2017 & South Africa [154] & Biorefineries & $1 \mathrm{MWh}$ electricity produced & $\begin{array}{l}\text { Aspen simulation/Existing } \\
\text { literature/Ecoinvent v3 }\end{array}$ & CML-IA baseline 3.02 \\
\hline 2017 & South Africa [155] & Biorefineries & $1 \mathrm{MWh}$ electricity produced & $\begin{array}{c}\text { Aspen simulation/Existing } \\
\text { literature/Ecoinvent }\end{array}$ & CML-IA baseline 3.02 \\
\hline 2017 & South Africa [156] & Biorefineries & $\begin{array}{l}1 \text { ton BD produced } / 1 \mathrm{MWh} \\
\text { electricity produced }\end{array}$ & $\begin{array}{l}\text { Aspen simulation/Existing } \\
\text { literature/Ecoinvent v3 }\end{array}$ & CML-IA baseline 3.02 \\
\hline 2017 & South Africa [157] & Zinc oxide & $\mathrm{ZnO}$ surface area $\left(1 \mathrm{~m}^{2} / \mathrm{g}\right)$ & Primary data/Existing literature & ReCiPe \\
\hline 2017 & South Africa [158] & Domestic Biogas Digester & $1 \mathrm{MJ}$ & Primary data & Other \\
\hline
\end{tabular}


Table 1. Cont.

\begin{tabular}{|c|c|c|c|c|c|}
\hline Year & Country [Ref.] & Product & Functional Unit & LCI Database & LCIA Method \\
\hline 2018 & South Africa [159] & Sandstone & $1 \mathrm{t}$ of sandstone & Primary data/Existing literature & IMPACT 2002+ \\
\hline 2018 & South Africa [160] & $\begin{array}{l}\text { Acid mine drainage (AMD) } \\
\text { treatment }\end{array}$ & $\begin{array}{c}1 \mathrm{~m}^{3} \text { of effluent generated by an } \\
\text { AMD reactor }\end{array}$ & $\begin{array}{l}\text { Primary data/Existing } \\
\text { literature/Ecoinvent v3 }\end{array}$ & ReCiPe2016 \\
\hline 2018 & South Africa [161] & Sanitation system & $\begin{array}{l}\text { The provision of a sanitation } \\
\text { service for the daily defecation of } \\
\text { a 10-adult occupant household in } \\
\text { South Africa }\end{array}$ & Primary data/Ecoinvent v3.0 & ReCiPe2016 \\
\hline 2018 & South Africa [162] & Soybean Biodiesel & $1 \mathrm{~L}$ of Biodiesel & Existing literature & Other \\
\hline 2019 & South Africa [164] & Seawater desalination & $1 \mathrm{~kL}$ of potable water & $\begin{array}{l}\text { Primary data/Existing } \\
\text { literature/Ecoinvent v3 }\end{array}$ & ReCiPe \\
\hline 2019 & South Africa [165] & $\begin{array}{l}\text { Method for the Construction } \\
\text { industry }\end{array}$ & - & - & - \\
\hline 2019 & South Africa [166] & Coal power plant & 712-MW power-generating unit & Primary data/Ecoinvent & Eco-Indicator 99 \\
\hline 2020 & South Africa [167] & Straw & $\begin{array}{l}\text { Annual straw consumption } \\
\text { per capita }\end{array}$ & $\begin{array}{l}\text { Primary data/Existing } \\
\text { literature/Ecoinvent v3.5 }\end{array}$ & ReCiPe \\
\hline 2020 & South Africa [16] & Review & - & - & - \\
\hline 2015 & South Africa [169] & Sugarcane & $\begin{array}{l}1 \text { ton of extractable sucrose } \\
\text { produced leaving the farm gate }\end{array}$ & Primary data & Other \\
\hline 2012 & South Africa [170] & Pork & $1 \mathrm{~kg}$ of pork (carcass weight) & Existing literature/Gabi 2006 & CML2001 \\
\hline 2012 & South Africa [171] & Saline wastewater & $\begin{array}{l}\text { A daily production of } 40 \text { ton of } \\
\text { dehydrated sodium sulphate by } \\
\text { each process and another } 960 \\
\text { ton/day of "ice + liquid water" } \\
\text { mixture in the amounts obtained } \\
\text { by EFC. }\end{array}$ & $\begin{array}{l}\text { Existing } \\
\text { literature/Ecoinvent v2.2 }\end{array}$ & IMPACT 2002+ \\
\hline 2012 & South Africa [172] & Water treatment & $\begin{array}{c}1000 \mathrm{~m}^{3} \text { of boiler feed water } \\
\text { (BFW) }\end{array}$ & Existing literature/Ecoinvent & CML 2 baseline 2000 V2.04 \\
\hline 2010 & South Africa [173] & Biodiesel & 1 ton of biodiesel & Primary data/Existing literature & Other \\
\hline 2010 & South Africa [174] & Biofuel & $\begin{array}{l}\text { A unit of product, over a } \\
\text { one-year production period }\end{array}$ & Primary data/Existing literature & - \\
\hline
\end{tabular}


Table 1. Cont.

\begin{tabular}{|c|c|c|c|c|c|}
\hline Year & Country [Ref.] & Product & Functional Unit & LCI Database & LCIA Method \\
\hline 2002 & South Africa [175] & Water recycling plant & $\begin{array}{c}1 \mathrm{~kL} \text { of water as supplied to } \\
\text { industry }\end{array}$ & Primary data/Gabi3 & CML \\
\hline 2007 & Tanzania [176] & $\begin{array}{l}\text { Production of biofuels from } \\
\text { pyrolysis of wood }\end{array}$ & One year & Primary data & Other \\
\hline 2012 & Tanzania [177] & Electricity & $\begin{array}{l}\text { The functional unit for this study } \\
\text { is } 1 \mathrm{MW} \text { het electricity at the } \\
\text { power plant. }\end{array}$ & Ecoinvent v2.2/USLCI 1.6.0 & CML(IA) \\
\hline 2013 & Tanzania [178] & $\begin{array}{l}\text { Bioethanol produced from } \\
\text { sugarcane molasses }\end{array}$ & $\begin{array}{c}1 \text { ton of combusted jatropha } \\
\text { biodiesel. }\end{array}$ & $\begin{array}{l}\text { Primary data/Existing } \\
\text { literature/Ecoinvent }\end{array}$ & CML (IA) \\
\hline 2014 & Tanzania [179] & Electricity & $\begin{array}{l}1 \mathrm{MWh} \text { gross electricity } \\
\text { generated at the power plant. }\end{array}$ & Ecoinvent v2.2/USLCI 1.6.0 & CML (IA) \\
\hline 2014 & Tanzania [180] & Maize & One ton of Maize & $\begin{array}{l}\text { Primary data/Existing } \\
\text { literature/Gabi } 4\end{array}$ & Other \\
\hline 2016 & Tanzania [181] & Review & - & - & - \\
\hline 2020 & Tanzania [182] & PV Electricity & $1 \mathrm{~m}^{2}$ of PV module & Primary data & Other \\
\hline 2007 & Tunisia [183] & Coastal area & $1 \mathrm{~L}$ of water sample & Primary data & Other \\
\hline 2012 & Tunisia [185] & Jatropha biodiesel & 1 hectare of Jatropha & Primary data/Existing literature & Other \\
\hline 2013 & Tunisia [186] & Olive-waste cake & $\begin{array}{l}1 \mathrm{~kg} \text { of AC from by-product } \\
\text { olive-waste cakes }\end{array}$ & $\begin{array}{l}\text { Primary data/Existing } \\
\text { literature/Ecoinvent v2.2 }\end{array}$ & CML 2 Baseline 2000 \\
\hline 2014 & Tunisia [187] & Groundwater pumping system & $\begin{array}{l}1 \mathrm{~m}^{3} \text { pumped at a } 35 \mathrm{~m} \text { depth, } 2 \\
\text { bars of pressure, and } 0.9 \text { bars of } \\
\text { friction losses in pipes }\end{array}$ & Ecoinvent v2.2 & ReCiPe \\
\hline 2015 & Tunisia [188] & Shale gas & $1 \mathrm{MJ}$ of shale gas & Primary data & ReCiPe v1.06 \\
\hline 2017 & Tunisia [189] & Sheep/chicken meat & $1 \mathrm{~kg}$ of carcass & Primary data/Existing literature & Other \\
\hline 2017 & Tunisia [190] & Sea cages & 1 ton of live fish & Primary data/Ecoinvent v3 & Other \\
\hline 2017 & Tunisia [191] & Seabass & 1 ton of fish at the fish farm gate & Primary data/Ecoinvent v3 & CML2 baseline 2000 \\
\hline 2017 & Tunisia [192] & Sulfuric acid production system & 1 ton of sulfuric acid & Primary data/Ecoinvent v3 & ILCD \\
\hline 2017 & Tunisia [193] & tomatoes & $\begin{array}{l}1 \text { ton of soilless geothermal } \\
\text { greenhouse cherry tomatoes }\end{array}$ & Primary data/Ecoinvent v3.3 & ILCD \\
\hline
\end{tabular}


Table 1. Cont.

\begin{tabular}{|c|c|c|c|c|c|}
\hline Year & Country [Ref.] & Product & Functional Unit & LCI Database & LCIA Method \\
\hline 2018 & Tunisia [194] & fisheries (seafood) & $\begin{array}{l}1 \text { ton of landed seafood by } \\
\text { demersal trawlers in the Gulf } \\
\text { of Gabes }\end{array}$ & Primary data/Ecoinvent v3 & CML baseline 2000 \\
\hline 2020 & Tunisia [196] & Ground water irrigation & Area of land cropped over 1 year & Primary data/Existing literature & ReCiPe 1.07 \\
\hline 2020 & Tunisia [197] & Tomatoes & $\begin{array}{l}1 \text { ton of soilless cherry tomato } \\
\text { produced. }\end{array}$ & $\begin{array}{c}\text { Primary data/Ecoinvent } \\
\text { v3.3/Agrifootprint } 3.0\end{array}$ & ILCD \\
\hline 2020 & Tunisia [198] & Electricity & $1 \mathrm{MWh}$ of electricity generated & Primary data/WIOD/SimaPro & ILCD \\
\hline 2020 & Tunisia [199] & Electricity & $1 \mathrm{kWh}$ of electricity output & Primary data/Existing literature & ILCD \\
\hline 2020 & Tunisia [200] & Olives & $\begin{array}{l}1 \text { ton of olives and } 1 \text { ha of } \\
\text { cultivated olive growing area }\end{array}$ & Primary data/Ecoinvent v3.2 & ILCD \\
\hline 2020 & Tunisia [201] & Seafood & $1 \mathrm{t}$ of landed seafood & Primary data/Ecoinvent v3 & ILCD \\
\hline 2013 & Uganda [202] & Sanitary products & $\begin{array}{l}\text { Number of sanitary pads needed } \\
\text { to provide effective protection } \\
\text { from menstruation for one } \\
\text { woman over one year. }\end{array}$ & Ecoinvent v2.2 & IMPACT 2002+ \\
\hline 2014 & Uganda [204] & Charcoal & $\begin{array}{c}1 \mathrm{~kg} \text { of charcoal produced } \\
\text { and utilized }\end{array}$ & Primary data/Existing literature & CML2001 \\
\hline 2016 & Uganda [205] & Water & 3.57 $\mathrm{L}$ of potable water & $\begin{array}{c}\text { Primary data/Existing } \\
\text { literature/SimaPro }\end{array}$ & Eco-Indicator 99 \\
\hline 2016 & Uganda [206] & Waste & $\begin{array}{l}1 \text { ton of impurity-free anima } \\
\text { waste treated to produce a } \\
\text { quality soil improver/fertilizer. }\end{array}$ & Primary data/Existing literature & CML \\
\hline 2019 & Uganda [207] & Juice, dry fruits & $\begin{array}{c}1 \mathrm{~L} \text { of packaged juice ready for } \\
\text { consumption } / 1 \mathrm{~kg} \text { of packaged } \\
\text { dried fruits including the } \\
\text { non-edible parts }\end{array}$ & Primary data/Existing literature & CML2001 \\
\hline 2012 & Zambia [208] & Biochar & 1 ton of maize & $\begin{array}{l}\text { Primary data/Existing } \\
\text { literature/Ecoinvent v2.2 }\end{array}$ & ReCiPe (a voir) \\
\hline 2017 & Zambia [209] & Biochar production System & $\begin{array}{l}\text { Preparation and sequestration of } \\
11 \mathrm{~kg} \text { biochar }\end{array}$ & $\begin{array}{l}\text { Primary data/Existing } \\
\text { literature/Ecoinvent v3.2 }\end{array}$ & ReCiPe \\
\hline
\end{tabular}


Table 1. Cont.

\begin{tabular}{|c|c|c|c|c|c|}
\hline Year & Country [Ref.] & Product & Functional Unit & LCI Database & LCIA Method \\
\hline 2007 & Zimbabwe [210] & Plastic carrier bags & $1 \mathrm{~kg}$ of polyethylene & $\begin{array}{c}\text { Primary data/Existing } \\
\text { literature/Gabi } 3\end{array}$ & Other \\
\hline 2007 & Zimbabwe [211] & Paper & $\begin{array}{l}53 \mathrm{gsm}\left(\mathrm{g} / \mathrm{m}^{2}\right) \text { newsprint paper } \\
\text { produced in Zimbabwe from the } \\
\text { pulping of pinewood }\end{array}$ & Primary data & Eco-Indicator 99 \\
\hline 2008 & Zimbabwe [212] & Vehicle leaf springs & One life-cycle & Primary data & Eco-Indicator 99 \\
\hline 2008 & Zimbabwe [213] & Cement & 1 ton of cement & Primary data & Eco-Indicator 99 \\
\hline 2015 & Zimbabwe [214] & Steel balls & $1 \mathrm{~kg}$ of steel & Primary data & Other \\
\hline 2019 & Zimbabwe [215] & $\begin{array}{c}\text { Municipal solid waste } \\
\text { management }\end{array}$ & Annual generation of MSW & Ecoinvent v3 & ReCiPe 2016 \\
\hline 2020 & Zimbabwe [216] & Waste & $\begin{array}{l}\text { Annual biodegradable waste } \\
\text { generation for Harare and its } \\
\text { dormitory towns }\end{array}$ & Existing literature/Ecoinvent v3 & ReCiPe 2016 v1.02 \\
\hline
\end{tabular}




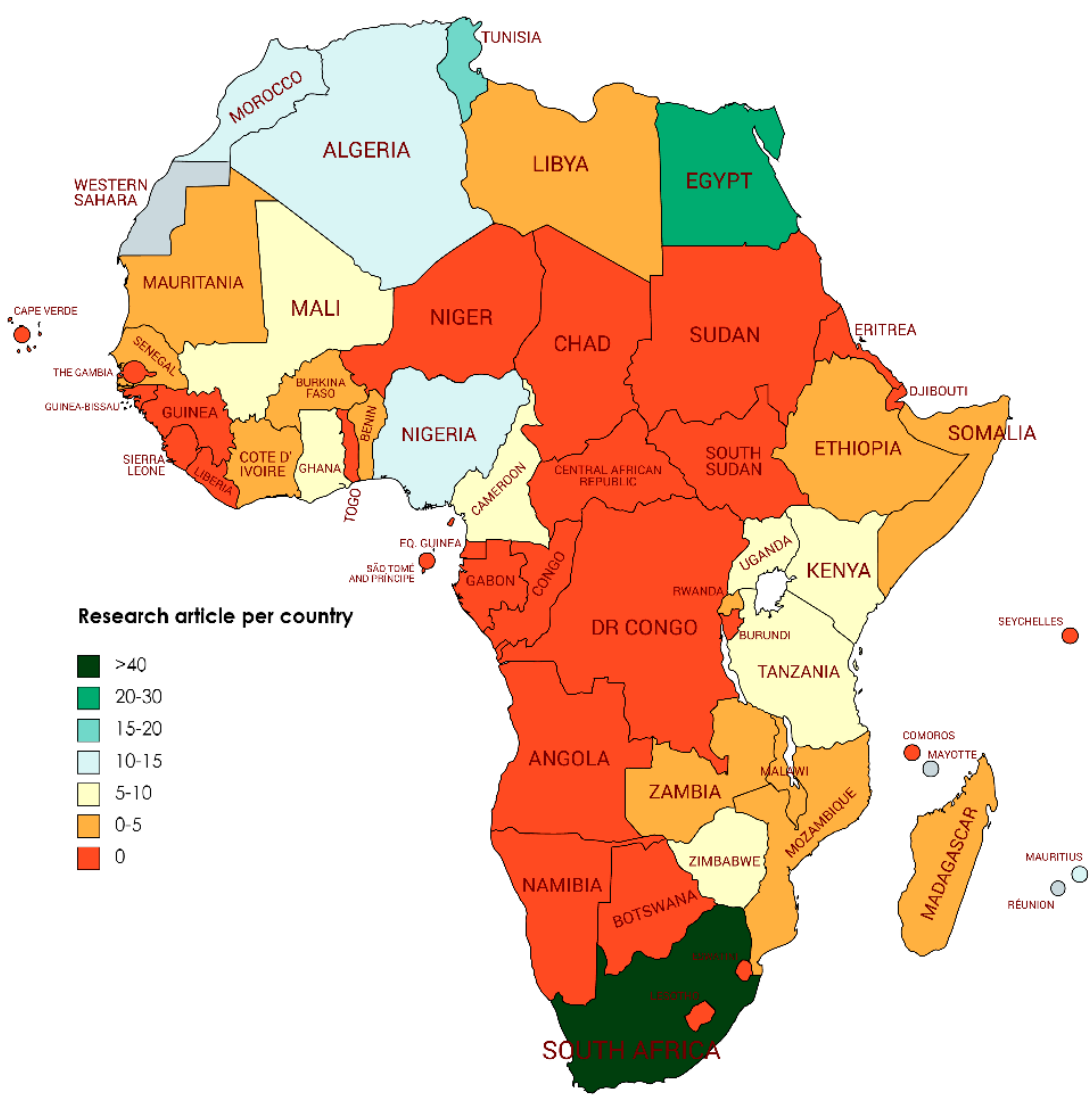

Figure 3. Research articles published per African country.

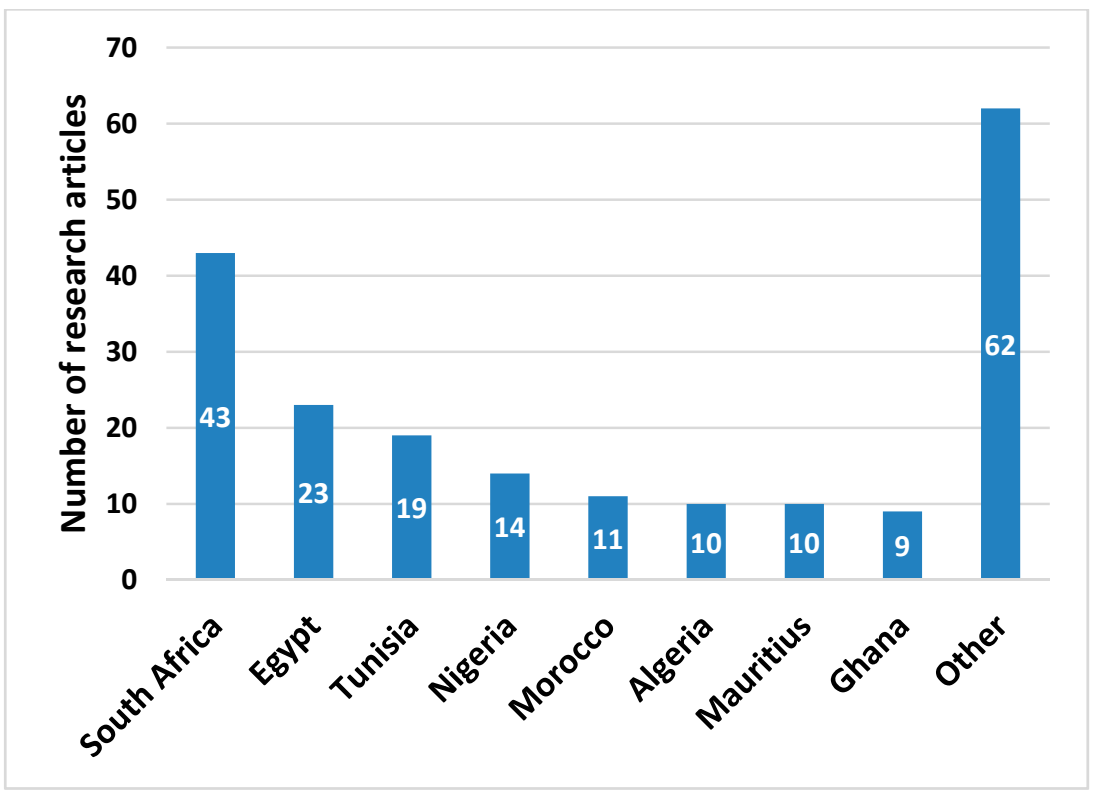

Figure 4. Research articles published for the eight most studied African countries.

\subsection{A Focus on LCA for Agricultural Products}

Several points can be highlighted regarding the research on agricultural products.

For fisheries, Lourguioui et al. [26] found in Algeria that a reduction of $3150 \mathrm{MJ}$ and $156 \mathrm{~kg} \mathrm{CO}_{2}$ eq per ton of fresh mussels could be reached if mussel farming activities would be operated in cooperation, instead of the traditional competitive scheme, as the resulting efficiency would be higher. The authors also highlighted the importance of applying LCA 
to the seafood production sector in Algeria. In Egypt [50], the importance of management practices was also highlighted to produce Nile Tilapia, carps, and mullets. By choosing better practices, life cycle impacts could be reduced by $22 \%$. In Tunisia $[184,191]$, it was shown that the production of seabass was an important source of nitrogen and phosphorus releases due to the fish feed. Cascade raceways featured higher impacts than traditional raceways. In sub-Saharan Africa, fish also constitute one of the main sources of animal protein. In Cameroon [37], the eutrophication impact was higher for Cameroon farms than for an intensive trout monoculture (France) or extensive carp polyculture (Brazil) due to poor water and poor manure management. In Senegal [132], F. Ziegler et al. found that artisanal fisheries have far lower inputs and emissions in the fishing phase compared with industrial fisheries. The global warming impacts from artisanal fisheries mainly come from the use of heavy fuel oil and low-quality refrigerants.

For the beef and dairy industries, D. Woldegebriela et al. [65] found out that milk production in Ethiopia had a higher global warming impact (1.75-2.22 $\mathrm{kg} \mathrm{CO} 2 \mathrm{eq} / \mathrm{kg}$ milk) than other developing countries due to the large amounts of low-quality feeds fed.

For fruit and vegetable products, C. Basset-Mens et al. [107] showed that compared with mangoes from Brazil or peaches/apples from France, it could be observed that except for terrestrial acidification and marine eutrophication, the results were higher for all the other impact categories for clementine production in Morocco. There are several reasons that explain these results: the higher amount of fertilizer used $(6 \mathrm{kgN} / \mathrm{kg})$ and the high amount of water needed to grow clementines $\left(8000 \mathrm{~m}^{3} /\right.$ hectare compared with 2.767 for apples grown in France), despite the fact that water is scarce in Morocco and it has to be withdrawn from more than 100 meter deep wells. The energy required to pump this water is also important (22,830 MJ per hectare compared with 2946 for mangoes grown in Brazil). Moreover, the Moroccan electricity mix is composed of more than 50\% fossil energy (coal), which explains why the impact of climate change was also high. S. Peyen et al. [105] also showed that tomato cultivation had a higher impact in Morocco than in France ( 28 vs. $7.5 \mathrm{~L} \mathrm{H}_{2} \mathrm{Oeq} / \mathrm{kg}$ ). They highlighted the importance of LCA for other impact categories (e.g., total energy consumption and global warming), which showed higher results in the case of France.

For forestry, in Ghana [73], it was found that the wastage of wood during timber processing contributed considerably to resource depletion, and land use impact was also a major concern, while kiln-dried lumber, plywood, and veneer production lines affected $\mathrm{CO}_{2}$ emissions considerably. Relatively high energy consumption was also reported due to biomass combustion for drying wood products.

For other types of crops such as cocoa [69], it was revealed that even though fertilizer and pesticide usage was low, the water consumption was higher in Ghana's plantations than in other parts of the world such as Ecuador or Indonesia. For cassava, a major crop cultivated mainly in Western Africa, it was calculated that the higher energy consumption came from planting operations, where the global warming potential (GWP) per one hectare was about $80 \mathrm{~kg} \mathrm{CO}$ eq.

\subsection{A Focus on LCA for Energy}

The second topic that has received interest is life cycle assessment for energy and electricity systems.

Jatropha is often one of the preferred choices in Africa to replace conventional transport fuel. In Burkina Faso [33], it was found that its production could reduce both GHG emissions and energy consumption by around $80 \%$ when compared with diesel fuel. One of the main challenges is the land transformation that implies the quantity of energy output per hectare was limited (less than $10 \mathrm{GJ} / \mathrm{ha}$ ). Therefore it could become a competitor of food crops. Another type of biodiesel is made using palm oil [35], where the results for Cameroon confirmed this tendency with a reduction of $70 \%$ compared with conventional fuel in the range of 60-80 $\mathrm{g} \mathrm{CO}_{2} / \mathrm{MJ}$. Proton-exchange membrane fuel cells have also received attention; however, the results found in Morocco [111] were much higher than 
those in Norway ( $4040 \mathrm{~g} \mathrm{CO}_{2}$ vs. $239 \mathrm{~g} / \mathrm{kWh}$ ) due to the electricity generation primarily based on fossil fuels for hydrogen production.

For cooking fuel, biogas is also an option to reduce the impacts of indoor air pollution. J. Lanche et al. [64] showed that 130,542 $\mathrm{t} \mathrm{CO}_{2}$ eq could be saved annually in Ethiopia if dung cakes were replaced with biogas. Indoor air pollution could also be avoided as dung combustion contributes to significant Nitrogen Oxide (NOx) and Particulate Matter (PM) emissions.

The use of renewables for electricity has been studied extensively. Several researchers have pointed out the need to develop photovoltaic (PV) systems and biomass power plants. R. Brizmohun et al. [103] pointed out the impacts of African fossil fuel power plant plants by analyzing the emissions of Mauritian plants. The global warming potential of electricity from coal was estimated to be $1444 \mathrm{~kg} \mathrm{CO} 2 \mathrm{eq} / \mathrm{MWh}$, which is about six times the minimum value obtained in the literature. The lack of abatement technology for PM2.5, $\mathrm{SO}_{2}$, and NOx was highlighted, as well as the higher sulphur content of the coal.

Wind power also received attention in Ethiopia [66]. Similar to studies conducted in developed countries, the $\mathrm{CO}_{2}$ emissions per $\mathrm{kWh}$ output were low, around $35 \mathrm{~g} \mathrm{CO}_{2} / \mathrm{kWh}$.

Electricity demand in the Middle East and North African (MENA) region has increased at a rate of $6-8 \%$ in recent years. To limit the impacts of this increase, a hybrid solar and biomass power plant was evaluated in Tunisia [199]; the GWP impact was found to be $22 \mathrm{~kg} \mathrm{CO}$ eq/MWh, with the boiler system and field having the greatest impact. Resource depletion and human toxicity were not negligible due to the solar field. Similar results were obtained in Morocco [113]. One of the solutions to promote renewables would be to retrofit existing dams to generate electricity from hydro power. This option was studied in Nigeria [125], finding corresponding values between 1.6 and $5.5 \mathrm{~kg} \mathrm{CO}_{2} \mathrm{eq} / \mathrm{MWh}$. It was highlighted that there were advantages in terms of saving on economic investments as well in that case.

Finally, the extraction of raw materials such as coal, oil or natural gas has not received as much attention, as further highlighted by A. Irhoma et al. [82] in Libya. The study showed that crude oil production and distillation had significant impacts. The impact of respiratory inorganics was also highlighted. The authors pushed for a reduction in fossil resources at refineries but also raised concerns for flaring and venting issues.

\section{Discussion}

\subsection{The Need for an African LCI Database}

As observed in several studies $[26,74,87,179]$ and highlighted furthermore in Table 1 , many of the LCA results obtained in the different studies were based on data from European-based LCI databases, namely, Ecoinvent or Gabi. Even though there has been progress in globalizing inventory processes from Ecoinvent v2 to Ecoinvent v3 [217], most of the processes are based on the situations in developed countries. Therefore, several important uncertainties may exist when using these data to evaluate African conditions, especially for the least developed African economies. To solve these limitations, the LifeCycle Initiative has promoted the "Global LCA Data Access network" (GLAD) to encourage the compatibility between the LCI databases and share information between different countries [218]. Several datasets can be found for African countries and future research could focus on improving these datasets.

\subsection{The Need for an African LCIA Method}

A second comment can be made when looking at the life cycle impact assessment (LCIA) methods used in the different studies. Many of the models have been developed based on the situation in developed countries (i.e., in terms of the population, population density, meteorological conditions, etc.). This point has also been raised by M. Ghazi et al [20]. Only a few studies in our review used a global life cycle impact assessment method, namely, ReCiPe2016 [10], Impact World+ [219] or LIME3 [220]. These methods provide characterization factors for each impact that is specific to the global region 
or country. The accuracy of the damage assessment can be greatly improved; however, limitations still exist, for example, models for air pollution damage in these methods divided Africa into only a limited number of regions. Some improvements could be made to further take into account the specific socio-economic disparities between African countries in these methods.

\subsection{Future Possible Topics of LCA Research}

In this section, some potential research topics are raised from economic and environmental points of view. Environmental data were mainly collected from global popular databases used in LCA such as EDGARv5.0 [221] or FAOSTAT [6], economic information from OEC [5], and the world factbook from CIA [222].

A remark concerning all African countries can be raised, even though several reports from the UNEP [223] have highlighted the potential impacts of second-hand vehicles in African countries (imported mainly from Europe and the USA), there is no research paper that has focused on second-hand vehicles in Africa, despite the fact that the global LCA community has focused extensively on transport. The impact of tourism could be also studied furthermore, as the concern for sustainable tourism has been raised in recent years [224].

A description for each African country is provided in Table 2, regarding each aforementioned topic. 
Table 2. Potential future topics of research. (x: no discussion topic).

\begin{tabular}{|c|c|c|c|}
\hline Country & Agriculture & Energy & Other \\
\hline Algeria & $\begin{array}{c}\text { - Wheat, one of the major crops there, was found to have a } \\
\text { green water footprint (WF) higher than global average } \\
\text { (3290 vs. } 1277 \mathrm{~m}^{3} / \text { ton) [225] }\end{array}$ & $\begin{array}{l}\text { - Attention could be paid to petroleum and natural gas } \\
\text { extraction as it contributes considerably to the country's } \\
\text { GDP. These two sectors represent } 15 \% \text { of the total } \mathrm{CO}_{2} \\
\text { emissions [221]. } \\
\text {-Electricity is almost only produced from natural gas [19], } \\
\text { where it represents } 25 \% \text { of the total } \mathrm{CO}_{2} \text { emissions [221] }\end{array}$ & - Road transport represents $25 \%$ of $\mathrm{CO}_{2}$ emissions [221] \\
\hline Angola & $\begin{array}{c}\text { - Cassava is a major source of revenue for agriculture, } \\
\text { where its green WF was found to be higher than the } \\
\text { global average ( } 819 \text { vs. } 550 \mathrm{~m}^{3} / \text { ton) [225] } \\
\text { - The burning of savanna represents more than } 70 \% \text { of } \\
\text { the } \mathrm{CO}_{2} \text { emissions from the agricultural sector [6] }\end{array}$ & $\begin{array}{c}\text { - Oil-related extraction contributes to about } 50 \% \text { of the } \\
\text { GDP [222] and about } 20 \% \text { of the country's } \mathrm{CO}_{2} \\
\text { emissions [221] }\end{array}$ & $\begin{array}{l}\text { - Road transport is the top sector for } \mathrm{CO}_{2} \text { emissions, } \\
\text { representing nearly } 25 \% \text { [221] }\end{array}$ \\
\hline Benin & $\begin{array}{c}\text { - Attention has already been paid to tomatoes as one of } \\
\text { the major sources of agricultural revenue. A focus on } \\
\text { cassava and yam production could be interesting, as } \\
\text { together they represent more than } 50 \% \text { of the country's } \\
\text { agricultural revenue [6] }\end{array}$ & $\begin{array}{l}\text { - More than } 50 \% \text { of the country's total energy supply is } \\
\text { from biofuel and waste products [19] }\end{array}$ & $\begin{array}{l}\text { - Road transport is the top sector for } \mathrm{CO}_{2} \text { emissions, } \\
\text { accounting for nearly } 75 \%[221]\end{array}$ \\
\hline Botswana & $\begin{array}{l}\text {-The country's agriculture is not well developed. Roots } \\
\text { and tubers account for most of the production [6] }\end{array}$ & $\begin{array}{l}\text { - Nearly } 100 \% \text { of the electricity is produced from coal } \\
\text { [19], where the sector represents more than } 50 \% \text { of the } \\
\qquad \mathrm{CO}_{2} \text { emissions [221] }\end{array}$ & $\begin{array}{l}\text { - Mining activities represent up to } 25 \% \text { of the country's } \\
\text { GDP [222], and this could be a potential research topic }\end{array}$ \\
\hline Burundi & $\begin{array}{c}\text { - Bananas and cassava together represent about } 50 \% \text { of } \\
\text { the revenue from agriculture [6]. Their green water } \\
\text { footprint was found to be higher than the global } \\
\text { average [225] }\end{array}$ & $\begin{array}{l}\text { - More than 95\% of the households use solid fuels for } \\
\text { cooking [226] }\end{array}$ & $\begin{array}{c}\text { - One third of the country's } \mathrm{CO}_{2} \text { emissions are from road } \\
\text { transport [221] }\end{array}$ \\
\hline Cameroon & $\begin{array}{l}\text { - Exports of timber (especially to China) have been } \\
\text { increasing in recent years (nearly 20\% of the exports) [5] }\end{array}$ & $\begin{array}{l}\text { - Oil production is a solid pillar of the economy [5] and it } \\
\text { is also the highest contributor to } \mathrm{CO}_{2} \text { emissions } \\
\qquad(43 \%) \text { [221] }\end{array}$ & $\begin{array}{l}\text { - Road transport is the } 2 n d \text { highest } \mathrm{CO}_{2} \text { emitter, } \\
\text { accounting for nearly } 25 \% \text { of the total [221] }\end{array}$ \\
\hline
\end{tabular}


Table 2. Cont.

\begin{tabular}{|c|c|c|c|}
\hline Country & Agriculture & Energy & Other \\
\hline Cabo Verde & $x$ & $x$ & $\begin{array}{l}\text { - The tourism industry mainly contributes to the } \\
\text { economy [222] }\end{array}$ \\
\hline Central African Republic & $x$ & $x$ & $\begin{array}{c}\text { - Gold and diamond mining significantly contribute to } \\
\text { the economy [5] }\end{array}$ \\
\hline Chad & $\begin{array}{c}\text { - The agricultural sector is reported to have the } 4^{\text {th }} \\
\text { highest } \mathrm{CO}_{2} \text { emissions in Africa, especially due to } \\
\text { savanna burning [6] }\end{array}$ & $\begin{array}{l}\text { - Oil is a major source of revenue ( } 85 \% \text { of the exports) } \\
\text { [5], where the sector represents more than more than one } \\
\text { third of country's } \mathrm{CO}_{2} \text { emissions [221] }\end{array}$ & $\begin{array}{c}\text { - Road transport accounts for more than one fifth of } \mathrm{CO}_{2} \\
\text { emissions [221] }\end{array}$ \\
\hline Comoros & $\begin{array}{c}\text { - Coconuts are a major crop product; their green water } \\
\text { footprint was found to be twice that of the global } \\
\text { average [225] }\end{array}$ & $x$ & $\begin{array}{l}\text { - Road transport contributes to nearly } 50 \% \text { of the } \\
\text { emissions [221] }\end{array}$ \\
\hline Congo DR & $\begin{array}{l}\text { - Cassava is the major crop produced, resulting in } \\
\text { significant land burning before plantation. The burning } \\
\text { of savanna represents more than } 80 \% \text { of the } \mathrm{CO}_{2} \\
\text { emissions from the agricultural sector [6] }\end{array}$ & $\begin{array}{c}\text { - Nearly } 100 \% \text { of the total energy supply is from biofuel } \\
\text { and waste products [19] }\end{array}$ & $\begin{array}{l}\text { - Mining products represent an important source of } \\
\text { revenue, especially copper and cobalt }[5]\end{array}$ \\
\hline Djibouti & $x$ & $x$ & $\begin{array}{l}\text { - Important transportation infrastructure (e.g., Addis } \\
\text { Ababa-Djibouti railway) has been under development } \\
\text { recently [222]. }\end{array}$ \\
\hline Egypt & $\begin{array}{l}\text { - The use of synthetic fertilizers contributes to about one } \\
\text { third of } \mathrm{CO}_{2} \text { emissions from the agricultural sector [6] }\end{array}$ & $\begin{array}{l}\text { - Electricity is mainly produced from fossil fuels (natural } \\
\text { gas) [19], where the sector represents almost } 40 \% \text { of } \mathrm{CO}_{2} \\
\text { emissions [221] }\end{array}$ & $\begin{array}{l}\text { - Road transport represents } 20 \% \text { of the } \mathrm{CO}_{2} \text { emissions } \\
\text { [221] }\end{array}$ \\
\hline Equatorial Guinea & $\begin{array}{l}\text { - Sweet potatoes and cassava are two major crops } \\
\text { produced in the country, where their green WF was found } \\
\text { to be four times higher than the global average [225] }\end{array}$ & $\begin{array}{l}\text { - The oil industry represents an importance source of } \\
\text { revenue (more than } 80 \% \text { of exports [5]) and it represents } \\
30 \% \text { of } \mathrm{CO}_{2} \text { emissions [221] }\end{array}$ & $\begin{array}{l}\text { - The chemical industry represents a source of revenue for } \\
\text { exports [5], where the sector represents } 30 \% \text { of country } \\
\qquad \mathrm{CO}_{2} \text { emissions [221] }\end{array}$ \\
\hline Eritrea & $\begin{array}{c}\text { - Sorghum is the main crop produced, where its green } \\
\text { WF was found with a water footprint more than twice } \\
\text { that of the global average [225] }\end{array}$ & $\begin{array}{l}\text { - Almost } 100 \% \text { of the electricity is produced from oil [19], } \\
\text { where the sector accounts for more than one half of the } \\
\qquad \mathrm{CO}_{2} \text { emissions [221] }\end{array}$ & $\begin{array}{l}\text { - Road transport accounts for more than } 20 \% \text { of } \mathrm{CO}_{2} \\
\text { emissions [221] }\end{array}$ \\
\hline Eswatini & - Sugarcane is the major crop produced in the country [6] & $\begin{array}{c}\text { - About one half of the country's } \mathrm{CO}_{2} \text { emissions are due } \\
\text { to the electricity sector [221] }\end{array}$ & $\begin{array}{l}\text { - Road transport accounts for about one third of } \mathrm{CO}_{2} \\
\text { emissions [221] }\end{array}$ \\
\hline Ethiopia & $\begin{array}{c}\text { - Emissions due to agriculture are reported to be the } \\
\text { highest in Africa, especially due to manure } \\
\text { management [6] }\end{array}$ & $\begin{array}{c}\text {-About } 90 \% \text { of the country's energy supply is from } \\
\text { biofuel and waste products [226] }\end{array}$ & $\begin{array}{l}\text { - Road transport accounts for about one third of } \mathrm{CO}_{2} \\
\text { emissions [221] }\end{array}$ \\
\hline
\end{tabular}


Table 2. Cont

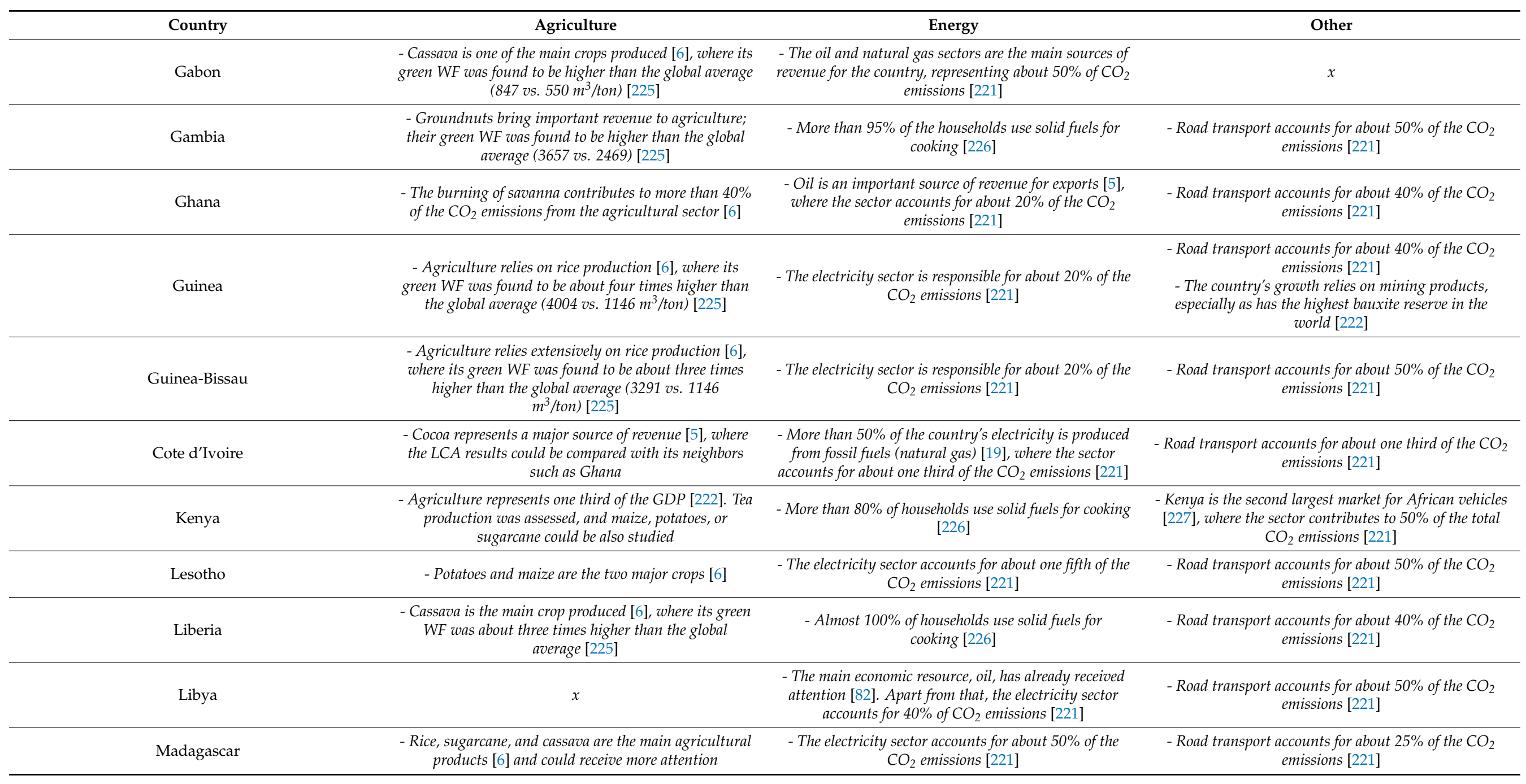


Table 2. Cont

\begin{tabular}{|c|c|c|c|}
\hline Country & Agriculture & Energy & Other \\
\hline Malawi & - The economy relies on tobacco for exports & $\begin{array}{l}\text { - The electricity sector accounts for one third of the } \mathrm{CO}_{2} \\
\text { emissions [221] }\end{array}$ & $\begin{array}{l}\text { - Road transport accounts for one third of the } \mathrm{CO}_{2} \\
\text { emissions [221] }\end{array}$ \\
\hline Mali & $\begin{array}{c}\text { - Rice and maize, the two main crops produced [6], were } \\
\text { found to have a green WF twice that of the global } \\
\text { average [225] }\end{array}$ & -Almost all households use solid fuels for cooking [226] & $\begin{array}{l}\text { - Road transport and cement production each account for } \\
\text { one third of the } \mathrm{CO}_{2} \text { emissions [221] }\end{array}$ \\
\hline Mauritania & -Rice is the major crop produced [6] & $\begin{array}{l}\text { - The electricity sector accounts for about } 20 \% \text { of } \mathrm{CO}_{2} \\
\text { emissions [221] }\end{array}$ & $\begin{array}{c}\text { - Road transport accounts for } 40 \% \text { of the } \mathrm{CO}_{2} \\
\text { emissions [221] }\end{array}$ \\
\hline Mauritius & $x$ & $\begin{array}{l}\text { - Fossil fuels represent } 50 \% \text { of electricity production [19], } \\
\text { accounting for more than } 60 \% \text { of } \mathrm{CO}_{2} \text { emissions [221] }\end{array}$ & $\begin{array}{l}\text { - Road transport accounts for } 25 \% \text { of the } \mathrm{CO}_{2} \text { emissions } \\
\text { [221] }\end{array}$ \\
\hline Morocco & $\begin{array}{l}\text { - The total energy consumption for agriculture is the } \\
\text { third highest in Africa (more than 50,000 terajoules [6]) }\end{array}$ & $\begin{array}{c}\text { - The electricity sector accounts for more than one third } \\
\text { of the } \mathrm{CO}_{2} \text { emissions [221], especially due to coal power } \\
\text { plants [19] }\end{array}$ & $\begin{array}{c}\text { - Morocco was also the first destination in Africa for } \\
\text { tourism (2018 data [228]), and the impact of the tourism } \\
\text { sector could receive attention }\end{array}$ \\
\hline Mozambique & $\begin{array}{l}\text { - Cassava is the major crop produced, where its green WF } \\
\text { was found to be twice that of the global average (1077 vs. } \\
500 \mathrm{~m}^{3} / \text { ton) [225] }\end{array}$ & $\begin{array}{c}\text { - More than 95\% of households use solid fuels for } \\
\text { cooking [226] }\end{array}$ & $\begin{array}{c}\text { - The country relies on mineral fuels (coal) and } \\
\text { aluminum for exports [5], and extraction processes could } \\
\text { be further analyzed }\end{array}$ \\
\hline Namibia & $\begin{array}{l}\text { - More than } 50 \% \text { of the } \mathrm{CO}_{2} \text { emissions related to } \\
\text { agricultural sector are due to the burning of savanna [6] }\end{array}$ & $x$ & $\begin{array}{l}\text { - The country relies on mineral extraction, such as } \\
\text { diamond and uranium extraction. }\end{array}$ \\
\hline Nigeria & $\begin{array}{c}\text { - Agriculture represents the second highest } \mathrm{CO}_{2} \\
\text { emissions in Africa [221]. Cassava has received attention, } \\
\text { and in addition, yams and maize could be examined as } \\
\text { other major crops [6] }\end{array}$ & $\begin{array}{c}\text { - Oil is a major source of revenue for the country [5], } \\
\text { where it represents } 20 \% \text { of the country's } \mathrm{CO}_{2} \text { emissions } \\
\text { [221] }\end{array}$ & $\begin{array}{c}\text { - Road transport accounts for about one third of the } \mathrm{CO}_{2} \\
\text { emissions [221] }\end{array}$ \\
\hline Republic of Congo & - Cassava and sugarcane are the two main crops [6] & $\begin{array}{l}\text { - Oil a major source of revenue for exports [5], where the } \\
\text { sector is responsible for } 50 \% \text { of the } \mathrm{CO}_{2} \text { emissions [221] }\end{array}$ & $\begin{array}{l}\text { - Road transport accounts for about one third of the } \mathrm{CO}_{2} \\
\text { emissions [221] }\end{array}$ \\
\hline Rwanda & $\begin{array}{l}\text { - The country mainly relies on agriculture, especially } \\
\text { bananas and cassava [6] }\end{array}$ & - Almost all households use solid fuels for cooking [226] & $\begin{array}{l}\text { - Road transport accounts for about } 40 \% \text { of the } \mathrm{CO}_{2} \\
\text { emissions [221] }\end{array}$ \\
\hline Sao tome \& Principe & $\begin{array}{c}\text { - Cocoa beans are a major source of revenue for } \\
\text { exports [5] }\end{array}$ & $x$ & $x$ \\
\hline Senegal & - Rice and groundnuts are the two main crops [6] & $\begin{array}{c}\text { - Most of the electricity is produced from oil, where the } \\
\text { sector contributes to about one quarter of the } \mathrm{CO}_{2} \\
\text { emissions [221] }\end{array}$ & $\begin{array}{c}\text { - Gold and phosphoric mining-related revenues have been } \\
\text { increasing in recent years [5] and could lead to an } \\
\text { increase in environmental impacts }\end{array}$ \\
\hline
\end{tabular}


Table 2. Cont.

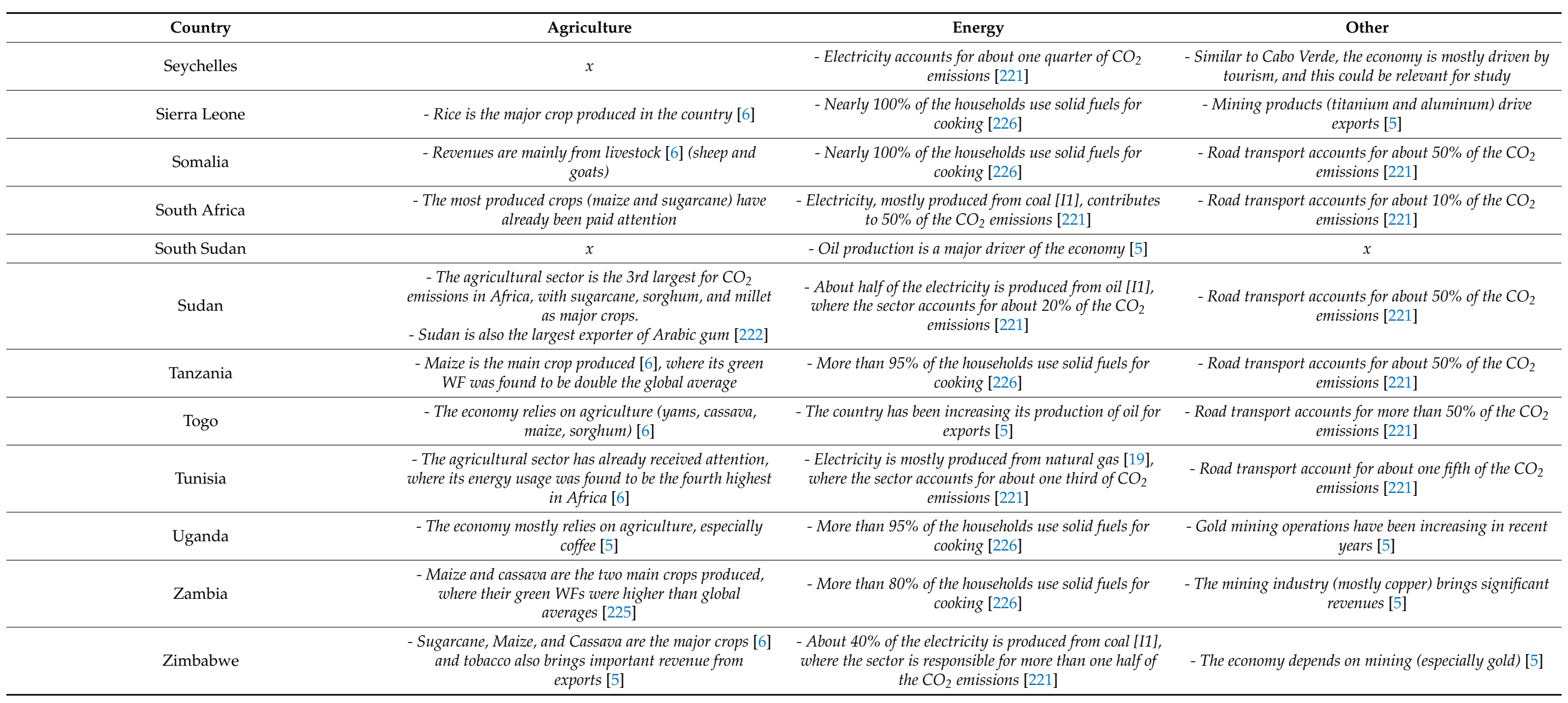




\section{Conclusions}

A total of 199 peer-reviewed LCA articles were found for Africa. The interest in LCA for the continent has been growing in the last ten years, but it remains far less than in other countries, including developing countries, located in Asia such as Thailand. The most active African countries are South Africa (43), Egypt (23), and Tunisia (19). It was observed that several countries (especially those in central Africa) were not paid attention. For example, a country such as the DR Congo, whose population may exceed 200 million in 2050, has not yet been the subject of research. With the predicted economic and population growth, the already existing environmental impacts might increase in Africa in the near future. The number of LCA researchers based in Africa is still limited, and it appears important to prioritize education and training of the life cycle thinking for the continent.

African LCA has mainly focused on agricultural products and energy, representing almost half of the research topics. Fisheries, fruits, and vegetables have received considerable attention as well as biofuel. However, several key products of the African economy were not paid attention such as second-hand vehicles or natural resources (oil, natural gas, mining products, etc.). With the African Continental Free Trade Area (AfCFTA) commencing as of 1 January 2021, trade between African countries might intensify, and the need for sustainable production could become very important.

As shown in Table 1, one of this review's key messages is that research has been mainly conducted with LCI databases that are not specific to African countries. The usage of global LCIA methods also remains scarce. Several key economic sectors for African countries have not yet been assessed.

This lack of tools specific to African countries to conduct LCA could lead to uncertainties in consequent results. Future research could probably focus on developing an LCI database that is specific to the African continent and on improving the resolution of impact assessment models to include a higher number of African regions.

Supplementary Materials: The following are available online at https://www.mdpi.com/2076-329 8/8/2/10/s1.

Author Contributions: Conceptualization, S.K. and N.I.; methodology, S.K.; formal analysis, S.K. and S.R.; investigation, S.K., S.R., M.M., C.-C.L.; writing—original draft preparation, S.K.; supervision, N.I; All authors have read and agreed to the published version of the manuscript.

Funding: This research received no external funding.

Institutional Review Board Statement: Not applicable.

Informed Consent Statement: Not applicable.

Data Availability Statement: All data is available in this manuscript.

Conflicts of Interest: The authors declare no conflict of interest. 


\section{Appendix A}

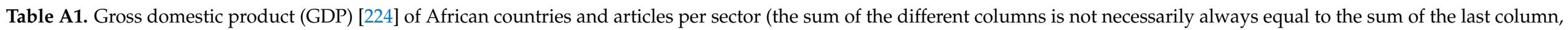
as, for example, "reviews" cannot be inserted into any sector)

\begin{tabular}{|c|c|c|c|c|c|}
\hline Country & Total GDP (PPP, Million USD) & $\begin{array}{c}\text { Share of GDP, Agriculture (\%) } \\
\text { [Nb of Articles] }\end{array}$ & $\begin{array}{c}\text { Share of GDP, Industry (\%) [Nb } \\
\text { of Articles] }\end{array}$ & $\begin{array}{c}\text { Share of GDP, Services (\%) [Nb } \\
\text { of Articles] }\end{array}$ & $\begin{array}{c}\text { Total Number of Research } \\
\text { Articles }\end{array}$ \\
\hline Algeria & 630,000 & $13.3[1]$ & $39.3[4]$ & $47.4[0]$ & 16 \\
\hline Angola & 193,600 & $10.2[0]$ & $61.4[0]$ & $28.4[0]$ & 0 \\
\hline Benin & 25,390 & $26.1[2]$ & $22.8[0]$ & $51.1[0]$ & 1 \\
\hline Botswana & 39,010 & $1.8[0]$ & $27.5[0]$ & $70.6[0]$ & 0 \\
\hline Burkina Faso & 35,850 & $31[0]$ & $23.9[4]$ & $44.9[0]$ & 4 \\
\hline Burundi & 8007 & $39.5[0]$ & $16.4[0]$ & $44.2[0]$ & 0 \\
\hline Cameroon & 89,540 & $16.7[1]$ & $26.5[3]$ & $56.8[1]$ & 5 \\
\hline Cape Verde & 3777 & $8.9[0]$ & $17.5[0]$ & $73.7[0]$ & 0 \\
\hline Central African Republic & 3390 & $43.2[0]$ & $16[0]$ & $40.8[0]$ & 0 \\
\hline Chad & 28,620 & $52.3[0]$ & $14.7[0]$ & $33.1[0]$ & 0 \\
\hline Comoros & 1319 & $47.7[0]$ & $11.8[0]$ & $40.5[0]$ & 0 \\
\hline $\begin{array}{c}\text { Democratic Republic of the } \\
\text { Congo }\end{array}$ & 68,600 & $19.7[0]$ & $43.6[0]$ & $36.7[0]$ & 0 \\
\hline Djibouti & 3640 & $2.4[0]$ & $17.3[0]$ & $80.2[0]$ & 0 \\
\hline Egypt & $1,204,000$ & $11.7[4]$ & 34.3 & 54 & 13 \\
\hline Equatorial Guinea & 31,520 & $2.5[0]$ & $54.6[0]$ & $42.9[0]$ & 0 \\
\hline Eritrea & 9402 & $11.7[0]$ & $29.6[0]$ & $58.7[0]$ & 0 \\
\hline Eswatini & 11,600 & $6.5[0]$ & $45[0]$ & $48.6[0]$ & 0 \\
\hline Ethiopia & 200,600 & $34.8[2]$ & $21.6[2]$ & 43.6 & 4 \\
\hline Gabon & 36,660 & $5[0]$ & $44.7[0]$ & $50.4[0]$ & 0 \\
\hline Guinea & 27,970 & $19.8[0]$ & $32.1[0]$ & $48.1[0]$ & 0 \\
\hline Guinea-Bissau & 3171 & $50[0]$ & $13.1[0]$ & $36.9[0]$ & 0 \\
\hline Ivory Coast & 97,160 & $20.1[0]$ & $26.6[1]$ & $53.3[0]$ & 1 \\
\hline Kenya & 163,700 & 34.5 & 17.8 & 47.5 & 7 \\
\hline Lesotho & 6656 & $5.8[0]$ & $39.2[0]$ & $54.9[1]$ & 1 \\
\hline Liberia & 6112 & $34[0]$ & $13.8[0]$ & $52.2[0]$ & 0 \\
\hline Libya & 61,970 & $1.3[0]$ & $52.3[2]$ & $46.4[0]$ & 2 \\
\hline Madagascar & 39,850 & $24[0]$ & $19.5[1]$ & $56.4[0]$ & 2 \\
\hline Malawi & 22,420 & $28.6[1]$ & $15.4[2]$ & $56[0]$ & 3 \\
\hline Mali & 41,220 & $41.8[3]$ & $18.1[1]$ & $40.5[0]$ & 6 \\
\hline Mauritania & 17,280 & $27.8[1]$ & $29.3[1]$ & $42.9[0]$ & 2 \\
\hline Mauritius & 28,270 & $4[2]$ & $21.8[2]$ & $74.1[9]$ & 13 \\
\hline Morocco & 298,600 & $14[4]$ & $29.5[6]$ & $56.5[1]$ & 11 \\
\hline Mozambique & 37,090 & $23.9[0]$ & $19.3[2]$ & $56.8[0]$ & 2 \\
\hline
\end{tabular}


Table A1. Cont.

\begin{tabular}{|c|c|c|c|c|c|}
\hline Country & Total GDP (PPP, Million USD) & $\begin{array}{c}\text { Share of GDP, Agriculture (\%) } \\
\text { [Nb of Articles] }\end{array}$ & $\begin{array}{c}\text { Share of GDP, Industry (\%) [Nb } \\
\text { of Articles] }\end{array}$ & $\begin{array}{c}\text { Share of GDP, Services (\%) [Nb } \\
\text { of Articles] }\end{array}$ & $\begin{array}{c}\text { Total Number of Research } \\
\text { Articles }\end{array}$ \\
\hline Namibia & 26,600 & $6.7[0]$ & $26.3[0]$ & $67[0]$ & 0 \\
\hline Niger & 21,860 & $41.6[0]$ & $19.5[0]$ & $38.7[0]$ & 0 \\
\hline Nigeria & $1,121,000$ & 21.1 & 22.5 & 56.4 & 19 \\
\hline Republic of the Congo & 29,390 & $9.3[0]$ & $51[0]$ & $39.7[0]$ & 0 \\
\hline Rwanda & 24,680 & 30.9 [1] & $17.6[0]$ & $51.5[0]$ & 1 \\
\hline São Tomé and Príncipe & 686 & $11.8[0]$ & $14.8[0]$ & $73.4[0]$ & 0 \\
\hline Senegal & 54,800 & $16.9[1]$ & $24.3[0]$ & $58.8[0]$ & 1 \\
\hline Seychelles & 2750 & $2.5[0]$ & $13.8[0]$ & $83.7[0]$ & 0 \\
\hline Sierra Leone & 11,550 & $60.7[0]$ & $6.5[0]$ & $32.9[0]$ & 0 \\
\hline Somalia & 20,440 & $60.2[0]$ & $7.4[0]$ & $32.5[1]$ & 1 \\
\hline South Africa & 767,200 & 2.8 & 29.7 & 67.5 & 21 \\
\hline South Sudan & & $-[0]$ & $-[0]$ & $-[0]$ & 0 \\
\hline Sudan & 177,400 & $39.6[0]$ & $2.6[0]$ & $57.8[0]$ & 0 \\
\hline Tanzania & 162,500 & $23.4[1]$ & $28.6[6]$ & $47.6[0]$ & 7 \\
\hline Togo & 12,970 & $28.8[0]$ & $21.8[0]$ & $49.8[0]$ & 0 \\
\hline Tunisia & 137,700 & $10.1[12]$ & $26.2[5]$ & $63.8[1]$ & 19 \\
\hline Uganda & 89,190 & $28.2[1]$ & $21.1[1]$ & $50.7[4]$ & 7 \\
\hline Zambia & 68,930 & $7.5[1]$ & $35.3[1]$ & $57[0]$ & 2 \\
\hline Zimbabwe & 34,270 & $12[0]$ & $22.2[5]$ & $65.8[2]$ & 7 \\
\hline
\end{tabular}




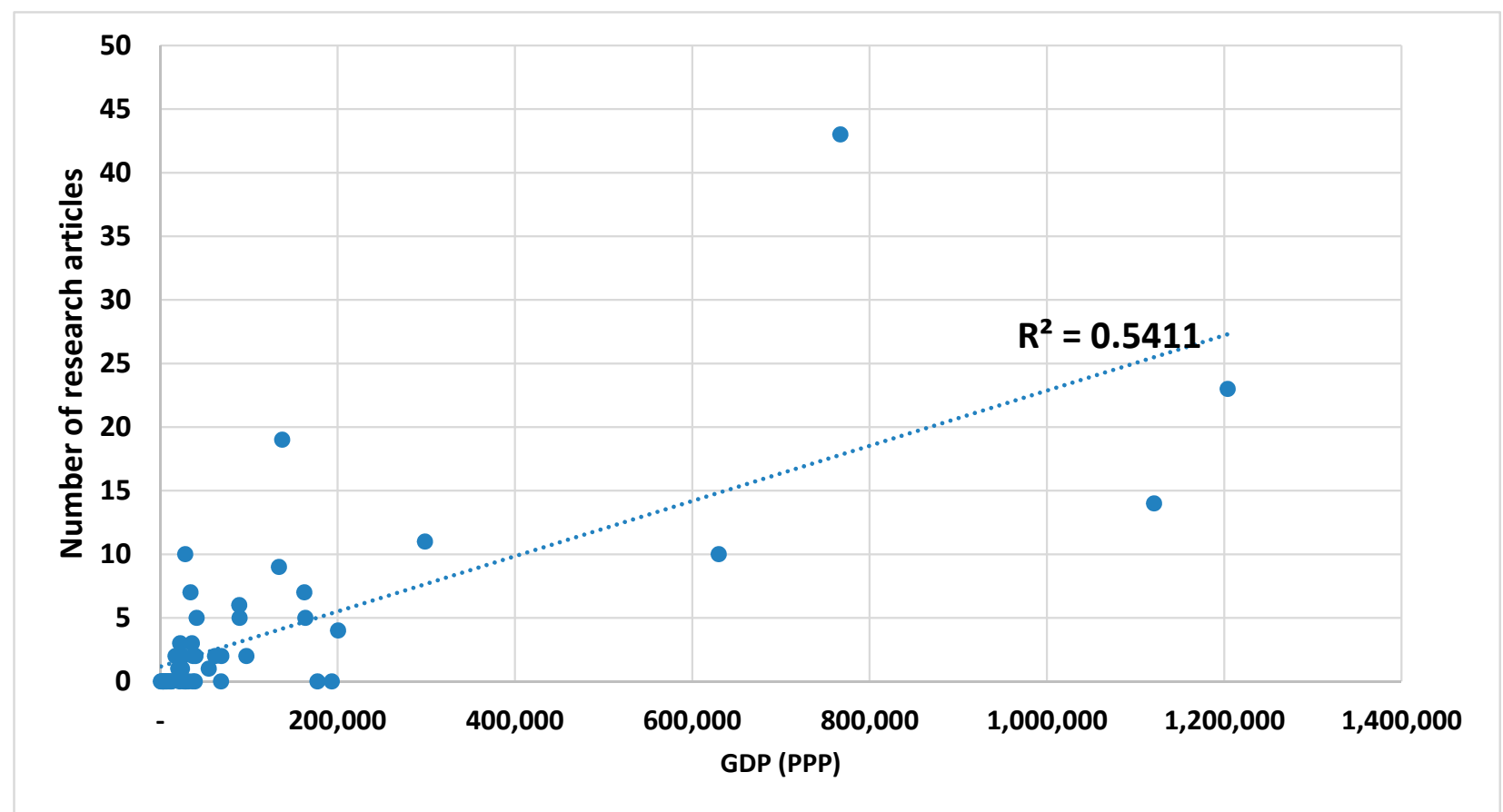

Figure A1. Correlation between the GDP (PPP) with the number of LCA research articles concerning each African country. 
Table A2. Summary of available life-cycle assessment (LCA) studies in Africa (Annex to Table 1).

\begin{tabular}{|c|c|c|c|c|}
\hline Country [Ref.] & System Boundaries & Allocation & Institution of the First Author & Location of the First Author \\
\hline Algeria [20] & Cradle to grave & No indication/no allocation & EOST & France \\
\hline Algeria [21] & Cradle to gate & No indication/no allocation & Boumerdes University & Algeria \\
\hline Algeria [22] & Cradle to grave & No indication/no allocation & Boumerdes University & Algeria \\
\hline Algeria [23] & Cradle to grave & No indication/no allocation & University of Boumerdes & Algeria \\
\hline Algeria [24] & Cradle to gate & No indication/no allocation & BADJI Mokhtar University & Algeria \\
\hline Algeria [25] & Cradle to grave & No indication/no allocation & University of Boumerdes & Algeria \\
\hline Algeria [27] & Cradle to grave & No indication/no allocation & University Saad Dahlab & Algeria \\
\hline Algeria [28] & Well-to-Tank & No indication/no allocation & Ecole Nationale Polytechnique & Algeria \\
\hline Algeria [29] & Cradle to grave & No indication/no allocation & Bougara University & Algeria \\
\hline Benin [30] & Cradle to gate & No indication/no allocation & CIRAD & France \\
\hline Benin [31] & Cradle to gate & No indication/no allocation & CIRAD & France \\
\hline Burkina Faso [32] & Cradle to grave & No indication/no allocation & $\begin{array}{l}\text { Escola Tècnica Superior d'Enginyeries } \\
\text { Industrial }\end{array}$ & Spain \\
\hline Burkina Faso [34] & Cradle to site & No indication/no allocation & $\begin{array}{l}\text { Universitat Politècnica de Catalunya } \\
\text { (UPC) }\end{array}$ & Spain \\
\hline Cameroon [35] & Well-to-Wheel & No indication/no allocation & KU Leuven & Belgium \\
\hline Cameroon [36] & Cradle to grave & No indication/no allocation & University of Yaoundé & Cameroon \\
\hline Cameroon [37] & Cradle to gate & Economic allocation & INRA & France \\
\hline Cameroon [38] & end-of-life & No indication/no allocation & University of Yaoundé & Cameroon \\
\hline Cameroon [39] & Well-to-Tank & energy allocation & University of Udine & Italy \\
\hline Egypt [40] & Cradle to site/end-of-life & No indication/no allocation & $\begin{array}{l}\text { Environment and Climate Research } \\
\text { Institute, Egypt }\end{array}$ & Egypt \\
\hline Egypt [41] & end-of-life & No indication/no allocation & National Water Research Center, Egypt & Egypt \\
\hline Egypt [42] & Not applicable & No indication/no allocation & E-JUST & Egypt \\
\hline Egypt [43] & Cradle to grave & No indication/no allocation & E-JUST & Egypt \\
\hline Egypt [44] & Not applicable & No indication/no allocation & E-JUST & Egypt \\
\hline
\end{tabular}


Table A2. Cont.

\begin{tabular}{|c|c|c|c|c|}
\hline Country [Ref.] & System Boundaries & Allocation & Institution of the First Author & Location of the First Author \\
\hline Egypt [45] & Cradle to gate & Economic allocation & Universita Politecnica delle Marche & Italy \\
\hline Egypt [46] & Not applicable & No indication/no allocation & E-JUST & Egypt \\
\hline Egypt [47] & Cradle to grave & No indication/no allocation & Riga Technical University & Latvia \\
\hline Egypt [48] & end-of-life & No indication/no allocation & E-JUST & Egypt \\
\hline Egypt [49] & Cradle to grave & No indication/no allocation & Parthenope University of Naples & Italy \\
\hline Egypt [50] & Cradle to gate & Mass and economic allocation & WorldFish & Malaysia \\
\hline Egypt [52] & Not applicable & No indication/no allocation & E-JUST & Egypt \\
\hline Egypt [53] & Cradle to gate & Mass and energy allocation & E-JUST & Egypt \\
\hline Egypt [54] & Cradle to gate & No indication/no allocation & Alexandria University & Egypt \\
\hline Egypt [55] & Cradle to gate & No indication/no allocation & E-JUST & Egypt \\
\hline Egypt [56] & end-of-life & No indication/no allocation & Alexandria University & Egypt \\
\hline Egypt [57] & Cradle to gate & No indication/no allocation & E-JUST & Egypt \\
\hline Egypt [58] & Cradle to grave & No indication/no allocation & $\begin{array}{l}\text { Ministry of Petroleum and Mineral } \\
\text { Resources, Alexandria, Egypt }\end{array}$ & Egypt \\
\hline Egypt [59] & end-of-life & No indication/no allocation & Mansoura University & Egypt \\
\hline Egypt [60] & end-of-life & No indication/no allocation & Mansoura University & Egypt \\
\hline Egypt [61] & Cradle to gate & No indication/no allocation & Cairo University & Egypt \\
\hline Egypt [62] & Cradle to gate & No indication/no allocation & University of Siena & Italy \\
\hline Ethiopia [63] & Cradle to gate & No indication/no allocation & Wageningen University & Netherlands \\
\hline Ethiopia [64] & Cradle to grave & No indication/no allocation & Universitat Hohenheim & Germany \\
\hline Ethiopia [65] & Cradle to gate & Economic allocation & Wageningen University & Netherlands \\
\hline Ethiopia [66] & Cradle to grave & Ecoinvent 3-allocation, default unit & Addis Ababa University & Ethiopia \\
\hline Ghana [67] & Cradle to grave & No indication/no allocation & University of Ghana & Ghana \\
\hline Ghana [68] & Cradle to gate & No indication/no allocation & The Hong Kong Polytechnic University & Hong Kong \\
\hline Ghana [69] & Cradle to grave & Mass and energy allocation & University of Genoa & Italy \\
\hline Ghana [70] & Cradle to gate & No indication/no allocation & Wageningen University & Netherlands \\
\hline Ghana [71] & Cradle to grave & No indication/no allocation & University of Ghana & Ghana \\
\hline
\end{tabular}


Table A2. Cont.

\begin{tabular}{|c|c|c|c|c|}
\hline Country [Ref.] & System Boundaries & Allocation & Institution of the First Author & Location of the First Author \\
\hline Ghana [72] & Cradle to grave & No indication/no allocation & Curtin University & Australia \\
\hline Ghana [73] & Cradle to gate & Physical and economical allocation & Wageningen University & Netherlands \\
\hline Ghana [74] & Cradle to gate & No indication/no allocation & $\begin{array}{l}\text { Kwame Nkrumah University of Science } \\
\text { \& Technology }\end{array}$ & Ghana \\
\hline Ivory Coast [75] & Well-to-Tank & energy allocation & Universite de Toulouse & France \\
\hline Kenya [76] & Cradle to gate & No indication/no allocation & Marks and Spencer & UK \\
\hline Kenya [77] & Cradle to grave & No indication/no allocation & Technical University of Denmark & Denmark \\
\hline Kenya [78] & Cradle to grave & No indication/no allocation & University of California & USA \\
\hline Kenya [79] & Cradle to gate & No indication/no allocation & University of Michigan & USA \\
\hline Kenya [80] & Gate to grave & No indication/no allocation & Umeå University & Sweden \\
\hline Libya [81] & Cradle to grave & No indication/no allocation & Nottingham Trent University & UK \\
\hline Libya [82] & Cradle to grave & No indication/no allocation & $\begin{array}{l}\text { The Higher Institute of Polytechnic } \\
\text { Professions }\end{array}$ & Libya \\
\hline Madagascar [83] & Cradle to grave? & No indication/no allocation & University of Antananarivo & Madagascar \\
\hline Madagascar [84] & Cradle to gate & No indication/no allocation & Université de la Réunion & France \\
\hline Malawi [86] & Cradle to site & No indication/no allocation & Edinburgh Napier University & UK \\
\hline Malawi [87] & Cradle to gate & Economic and mass allocation & University of Exeter & UK \\
\hline Mali [88] & Cradle to grave & No indication/no allocation & Higher Technical Institute, Cyprus & Cyprus \\
\hline Mali [89] & Cradle to gate & No indication/no allocation & KU Leuven & Belgium \\
\hline Mali [90] & Cradle to gate & No indication/no allocation & KU Leuven & Belgium \\
\hline Mali [91] & Cradle to gate & No indication/no allocation & University of South Florida & USA \\
\hline Mali [92] & Cradle to gate & Economic allocation & CIRAD & France \\
\hline Mauritania [93] & Cradle to gate & Mass allocation & University of Santiago de Compostela & Spain \\
\hline Mauritania [94] & Cradle to gate & No indication/no allocation & $\begin{array}{l}\text { Instituto Eduardo Torroja de ciencias de } \\
\text { la construcción }\end{array}$ & Spain \\
\hline Mauritius [99] & end-of-life & No indication/no allocation & University of Mauritius & Mauritius \\
\hline Mauritius [100] & Cradle to grave & Economic allocation & University of Mauritius & Mauritius \\
\hline Mauritius [101] & Cradle to grave & No indication/no allocation & University of Mauritius & Mauritius \\
\hline
\end{tabular}


Table A2. Cont.

\begin{tabular}{|c|c|c|c|c|}
\hline Country [Ref.] & System Boundaries & Allocation & Institution of the First Author & Location of the First Author \\
\hline Mauritius [102] & Cradle to grave & No indication/no allocation & University of Mauritius & Mauritius \\
\hline Mauritius [103] & Cradle to site & Economic and mass allocation & University of Mauritius & Mauritius \\
\hline Mauritius [104] & end-of-life & No indication/no allocation & Sotravic Lte & Mauritius \\
\hline Mauritius [95] & Cradle to grave & Economic allocation & University of Mauritius & Mauritius \\
\hline Mauritius [96] & end-of-life & No indication/no allocation & University of Mauritius & Mauritius \\
\hline Mauritius [97] & Cradle to site & Economic allocation & University of Mauritius & Mauritius \\
\hline Morocco [105] & Cradle to gate & Mass allocation & ADEME & France \\
\hline Morocco [106] & Cradle to gate & No indication/no allocation & CIRAD & France \\
\hline Morocco [107] & Cradle to gate & Economic allocation & CIRAD & France \\
\hline Morocco [108] & Cradle to gate & No indication/no allocation & Universidad Politécnica de Madrid & Spain \\
\hline Morocco [109] & Cradle to grave & No indication/no allocation & INES & France \\
\hline Morocco [110] & Cradle to gate & No indication/no allocation & CIRAD & France \\
\hline Morocco [111] & Cradle to grave & No indication/no allocation & University of Ljubljana & Slovenia \\
\hline Morocco [113] & Cradle to grave & Economic allocation & CIEMAT & Spain \\
\hline Morocco [114] & Cradle to grave? & No indication/no allocation & Mohammed V University & Morocco \\
\hline Morocco [115] & Cradle to gate & No indication/no allocation & Mohammadia School of Engineering & Morocco \\
\hline Mozambique [116] & Well-to-Wheel & Mass allocation & Chalmers University of Technology & Sweden \\
\hline Mozambique [117] & Cradle to site & Mass allocation & $\begin{array}{l}\text { Swedish University of Agricultural } \\
\text { Sciences }\end{array}$ & Morocco \\
\hline Nigeria [118] & Cradle to grave & No indication/no allocation & University of Manchester & UK \\
\hline Nigeria [119] & Cradle to grave? & No indication/no allocation & Iowa State University & USA \\
\hline Nigeria [120] & Cradle to gate & No indication/no allocation & Covenant University & Nigeria \\
\hline Nigeria [121] & end-of-life & No indication/no allocation & $\begin{array}{l}\text { National Water Quality Reference } \\
\text { Laboratory Minna }\end{array}$ & Nigeria \\
\hline Nigeria [122] & Well-to-Wheel & Mass allocation & Cranfield University & UK \\
\hline Nigeria [123] & Gate to gate & No indication/no allocation & University of Ibadan & Nigeria \\
\hline Nigeria [124] & Cradle to grave & No indication/no allocation & University of Tlemcen & Algeria \\
\hline
\end{tabular}


Table A2. Cont.

\begin{tabular}{|c|c|c|c|c|}
\hline Country [Ref.] & System Boundaries & Allocation & Institution of the First Author & Location of the First Author \\
\hline Nigeria [125] & Cradle to grave & No indication/no allocation & Hohai University & China \\
\hline Nigeria [126] & Cradle to grave & No indication/no allocation & $\begin{array}{l}\text { Nigerian Stored Products Research } \\
\text { Institute }\end{array}$ & Nigeria \\
\hline Nigeria [127] & Cradle to gate & No indication/no allocation & Landmark University & Nigeria \\
\hline Nigeria [128] & Cradle to gate & No indication/no allocation & Adeleke University & Nigeria \\
\hline Nigeria [129] & Cradle to grave & No indication/no allocation & The University of Manchester & UK \\
\hline Nigeria [130] & Cradle to gate & No indication/no allocation & $\begin{array}{l}\text { Ladoke Akintola University of } \\
\text { Technology }\end{array}$ & Nigeria \\
\hline Nigeria, ghhana, ivory coast [13] & Not applicable & No indication/no allocation & The University of Manchester & South Africa \\
\hline Rwanda [131] & Cradle to gate & Mass allocation & CIRAD & France \\
\hline Senegal [132] & Cradle to gate & Economic allocation & $\begin{array}{l}\text { The Swedish Institute for Food and } \\
\text { Biotechnology }\end{array}$ & Sweden \\
\hline Somalia [133] & Cradle to grave & Mass allocation & University of Siena & Italy \\
\hline South Africa [134] & Not applicable & No indication/no allocation & University of Pretoria & South Africa \\
\hline South Africa [135] & Cradle to gate & Mass allocation & University of Pretoria & South Africa \\
\hline South Africa [137] & Not applicable & No indication/no allocation & University of Pretoria & South Africa \\
\hline South Africa [138] & Cradle to site & No indication/no allocation & University of Pretoria, & South Africa \\
\hline South Africa [139] & Cradle to grave & No indication/no allocation & University of KwaZulu-Natal & South Africa \\
\hline South Africa [140] & Cradle to gate & No indication/no allocation & CSIR, South africa & South Africa \\
\hline South Africa [141] & Cradle to grave & No indication/no allocation & Huawei Technologies CO., Ltd & China \\
\hline South Africa [142] & end-of-life & Mass allocation & University of Cape Town & South Africa \\
\hline South Africa [143] & Cradle to gate & No indication/no allocation & University of Pretoria & South Africa \\
\hline South Africa [144] & Cradle to gate & No indication/no allocation & University of Catania & Italy \\
\hline South Africa [145] & Well-to-Wheel & Economic allocation & University of Stellenbosch & South Africa \\
\hline South Africa [146] & Cradle to gate & Mass allocation & University of KwaZulu-Natal & South Africa \\
\hline South Africa [147] & Not applicable & No indication/no allocation & University of Johannesburg & South Africa \\
\hline South Africa [148] & Cradle to grave & No indication/no allocation & University of Cape Town & South Africa \\
\hline South Africa [149] & Cradle to gate & Economic allocation & Stellenbosch University & South Africa \\
\hline South Africa [150] & Cradle to grave & Physical allocation & Stellenbosch University & South Africa \\
\hline
\end{tabular}


Table A2. Cont.

\begin{tabular}{|c|c|c|c|c|}
\hline Country [Ref.] & System Boundaries & Allocation & Institution of the First Author & Location of the First Author \\
\hline South Africa [151] & Cradle to gate & No indication/no allocation & Zurich University of Applied Sciences & Swiss \\
\hline South Africa [152] & Cradle to gate & Mass allocation & University of Cape Town & South Africa \\
\hline South Africa [153] & Cradle to gate & Economic and energy allocation & Stellenbosch University & South Africa \\
\hline South Africa [154] & Cradle to gate & Economic allocation & University of Stellenbosch & South Africa \\
\hline South Africa [155] & Cradle to gate & Economic and energy allocation & University of Stellenbosch & South Africa \\
\hline South Africa [156] & Cradle to gate & Economic allocation & University of Stell+D170:D182enbosch & South Africa \\
\hline South Africa [158] & Cradle to gate & No indication/no allocation & University of Johannesburg & South Africa \\
\hline South Africa [16] & Not applicable & No indication/no allocation & University of the Witwatersrand & South Africa \\
\hline South Africa [159] & Cradle to gate & No indication/no allocation & University of Johannesburg & South Africa \\
\hline South Africa [160] & Cradle to gate & No indication/no allocation & $\begin{array}{l}\text { Council for Scientific and Industrial } \\
\text { Research(CSIR) }\end{array}$ & South Africa \\
\hline South Africa [161] & Cradle to grave & No indication/no allocation & Cranfield University & UK \\
\hline South Africa [162] & Well-to-Wheel & Mass allocation & University of Johannesburg & South Africa \\
\hline South Africa [164] & Cradle to gate & No indication/no allocation & University of KwaZulu-Natal & South Africa \\
\hline South Africa [165] & Not applicable & No indication/no allocation & University of Johannesburg & South Africa \\
\hline South Africa [166] & Cradle to grave & No indication/no allocation & Mount Royal University Calgary & Canada \\
\hline South Africa [167] & Cradle to grave & Mass allocation & University of Cape Town & South Africa \\
\hline South Africa [168] & Cradle to gate & No indication/no allocation & Tshwane University of Technology & South Africa \\
\hline South Africa [169] & Cradle to gate & No indication/no allocation & $\begin{array}{l}\text { South African Sugarcane Research } \\
\text { Institute }\end{array}$ & South Africa \\
\hline South Africa [170] & Cradle to gate & Mass allocation & KU Leuven & Belgium \\
\hline South Africa [171] & Cradle to gate & No indication/no allocation & University of Cape Town & South Africa \\
\hline South Africa [172] & Cradle to gate & No indication/no allocation & University of Cape Town & South Africa \\
\hline South Africa [173] & Well-to-Wheel & Economic allocation & University of Cambridge & UK \\
\hline South Africa [174] & Cradle to gate & No indication/no allocation & Stellenbosch University & South Africa \\
\hline South Africa [175] & Cradle to gate & Mass allocation & University of Natal & South Africa \\
\hline
\end{tabular}


Table A2. Cont.

\begin{tabular}{|c|c|c|c|c|}
\hline Country [Ref.] & System Boundaries & Allocation & Institution of the First Author & Location of the First Author \\
\hline Tanzania [176] & Cradle to grave & No indication/no allocation & University of Dar es Salaam & Tanzania \\
\hline Tanzania [177] & Cradle to gate & No indication/no allocation & $\begin{array}{c}\text { King Mongkut's University of } \\
\text { Technology }\end{array}$ & Thailand \\
\hline Tanzania [178] & Well-to-Wheel & energy allocation & University of Dar es Salaam & Tanzania \\
\hline Tanzania [179] & Cradle to site & No indication/no allocation & Tropical Pesticides Research Institute & Tanzania \\
\hline Tanzania [180] & Cradle to gate & No indication/no allocation & Yara International & Germany \\
\hline Tanzania [181] & Not applicable & No indication/no allocation & Tropical Pesticides Research Institute & Tanzania \\
\hline Tanzania [182] & Cradle to gate & No indication/no allocation & $\begin{array}{l}\text { Research Institute of Electric Power } \\
\text { Industry, Japan }\end{array}$ & Japan \\
\hline Tunisia [183] & Not applicable & No indication/no allocation & CNRS & France \\
\hline Tunisia [184] & Cradle to gate & No indication/no allocation & Université de Monastir & Tunisia \\
\hline Tunisia [185] & Cradle to gate & No indication/no allocation & University of Sfax & Tunisia \\
\hline Tunisia [186] & Cradle to gate & No indication/no allocation & Universitat Autònoma de Barcelona & Spain \\
\hline Tunisia [187] & Cradle to grave? & No indication/no allocation & IRSTEA & France \\
\hline Tunisia [188] & Cradle to gate & No indication/no allocation & $\begin{array}{l}\text { Institut National des Sciences Appliquée } \\
\text { Technologie }\end{array}$ & Tunisia \\
\hline Tunisia [189] & Cradle to gate & No indication/no allocation & Université de Carthage & Tunisia \\
\hline Tunisia [190] & Cradle to gate & No indication/no allocation & Université de Carthage & Tunisia \\
\hline Tunisia [191] & Cradle to gate & No indication/no allocation & Université de Carthage & Tunisia \\
\hline Tunisia [192] & Cradle to gate & No indication/no allocation & National School of Engineers of Gabes & Tunisia \\
\hline Tunisia [193] & Cradle to gate & No indication/no allocation & Gabes University & Tunisia \\
\hline Tunisia [194] & Cradle to gate & No indication/no allocation & Université de Carthage & Tunisia \\
\hline Tunisia [195] & Cradle to gate & No indication/no allocation & CIRAD & France \\
\hline Tunisia [196] & Cradle to grave? & No indication/no allocation & CIRAD & France \\
\hline Tunisia [197] & Cradle to gate & No indication/no allocation & Université de Gabès & Tunisia \\
\hline Tunisia [198] & Cradle to grave & No indication/no allocation & CIEMAT & Spain \\
\hline Tunisia [199] & Cradle to grave & Economic allocation & CIEMAT & Spain \\
\hline Tunisia [200] & Cradle to gate & No indication/no allocation & (IFAPA) & Spain \\
\hline Tunisia [201] & Cradle to gate & No indication/no allocation & Cranfield University & UK \\
\hline
\end{tabular}


Table A2. Cont.

\begin{tabular}{|c|c|c|c|c|}
\hline Country [Ref.] & System Boundaries & Allocation & Institution of the First Author & Location of the First Author \\
\hline Uganda [202] & Cradle to grave & No indication/no allocation & Makerere University & Uganda \\
\hline Uganda [203] & end-of-life & No indication/no allocation & $\begin{array}{c}\text { National Water \& Sewerage Corporation, } \\
\text { Uganda }\end{array}$ & Uganda \\
\hline Uganda [204] & Cradle to grave & No indication/no allocation & University of Hohenheim & Germany \\
\hline Uganda [205] & Cradle to gate & No indication/no allocation & University of South Florida & USA \\
\hline Uganda [206] & end-of-life & No indication/no allocation & Makerere University & Uganda \\
\hline Uganda [207] & Gate to gate & No indication/no allocation & $\begin{array}{l}\text { Makerere University College of } \\
\text { Agricultural \& Environmental Sciences }\end{array}$ & Uganda \\
\hline Zambia [208] & Cradle-to-gate? & No indication/no allocation & Norwegian Geotechnical Institute (NGI) & Norway \\
\hline Zambia [209] & Cradle-to-gate? & No indication/no allocation & Norwegian Geotechnical Institute (NGI) & Norway \\
\hline Zimbabwe [210] & Cradle to gate & Mass allocation & University of Zimbabwe, & Zimbabwe \\
\hline Zimbabwe [211] & Cradle to gate & No indication/no allocation & University of Johannesburg & South Africa \\
\hline Zimbabwe [212] & Cradle to grave & No indication/no allocation & University Of Johannesburg & South Africa \\
\hline Zimbabwe [213] & Cradle to gate & No indication/no allocation & University Of Johannesburg & South Africa \\
\hline Zimbabwe [214] & Cradle to grave & No indication/no allocation & University of Zimbabwe & Zimbabwe \\
\hline Zimbabwe [216] & end-of-life & No indication/no allocation & University of Johannesburg & South Africa \\
\hline
\end{tabular}




\section{References}

1. United Nations. 2019 Revision of World Population Prospects. Available online: https://population.un.org/wpp/Download/ Standard/Population/ (accessed on 31 December 2020).

2. PWC. The World in 2050. Available online: https://www.pwc.com/gx/en/research-insights/economy/the-world-in-2050.html (accessed on 31 December 2020).

3. UNEP. AEO3. Available online: https://wedocs.unep.org/handle/20.500.11822/8391 (accessed on 31 December 2020).

4. WHO. Available online: https://apps.who.int/gho/data/node.main.BODAMBIENTAIRDTHS?lang=en (accessed on 31 December 2020).

5. MIT Media Lab, OEC. Available online: https:// oec.world/en (accessed on 31 December 2020).

6. FAO. Faostat Database. Available online: http://www.fao.org/faostat/en/\#data (accessed on 31 December 2020).

7. Bjørn, A.; Owsianiak, M.; Laurent, A.; Molin, C.; Westh, T.B.; Hauschild, M.Z. Mapping and characterization of LCA networks. Int. J. Life Cycle Assess. 2013, 18, 812-827. [CrossRef]

8. Karkour, S.; Ichisugi, Y.; Abeynayaka, A.; Itsubo, N. External-Cost Estimation of Electricity Generation in G20 Countries: Case Study Using a Global Life-Cycle Impact-Assessment Method. Sustainability 2020, 12, 2002. [CrossRef]

9. Ecoinvent Database. Available online: https://www.ecoinvent.org/ (accessed on 31 December 2020).

10. Huijbregts, M.A.J.; Steinmann, Z.J.N.; Elshout, P.M.F.; Stam, G.; Verones, F.; Vieira, M.; Zijp, M.; Hollender, A.; Zelm, v.R. ReCiPe2016: A harmonised life cycle impact assessment method at midpoint and endpoint level. Int. J. Life Cycle Assess. 2017, 22, 138-147. [CrossRef]

11. Ladenika, A.O.; Bodunrin, M.O.; Burman, N.W.; Croft, J.; Engelbrecht, S.; Goga, T.; MacGregor, O.S.; Maepa, M.; Harding, K.G. Assessing the availability of life cycle assessments in Austria. Int. J. Life Cycle Assess. 2019, 24, 614-619. [CrossRef]

12. Zanghelini, G.M.; de Souza Junior, H.R.A.; Kulay, L.; Cherubini, E.; Ribeiro, P.T.; Soares, S.R. A bibliometric overview of Brazilian LCA research. Int. J. Life Cycle Assess. 2016, 21, 1759-1775. [CrossRef]

13. Maepa, M.; Bodunrin, M.O.; Burman, N.W.; Croft, J.; Engelbrecht, S.; Ladenika, A.O.; MacGregor, O.S.; Harding, K.G. Review: Life cycle assessments in Nigeria, Ghana, and Ivory Coast. Int. J. Life Cycle Assess. 2017, 22, 1159-1164. [CrossRef]

14. Wiloso, E.I.; Nazir, N.; Hanafi, J.; Siregar, K.; Harsono, S.S.; Setiawan, A.A.R.; Muryanto; Romli, M.; Utama, N.A.; Shantiko, B. Life cycle assessment research and application in Indonesia. Int. J. Life Cycle Assess. 2019, 24, 386-396. [CrossRef]

15. Burman, N.W.; Croft, J.; Engelbrecht, S.; Ladenika, A.O.; MacGregor, O.S.; Maepa, M.; Bodunrin, M.O.; Harding, K.G. Review: Life-cycle assessment, water footprinting, and carbon footprinting in Portugal. Int. J. Life Cycle Assess. 2018, 23, 1693-1700. [CrossRef]

16. Harding, K.G.; Friedrich, E.; Jordaan, H.; le Roux, B.; Notten, P.; Russo, V.; Notten, P.; Russo, V.; Suppen-Reynaga, N.; Laan, M.v.d.; et al. Status and prospects of life cycle assessments and carbon and water footprinting studies in South Africa. Int. J. Life Cycle Assess. 2020, 26, 26-49. [CrossRef]

17. Croft, J.; Engelbrecht, S.; Ladenika, A.O.; MacGregor, O.S.; Maepa, M.; Bodunrin, M.O.; Burman, N.W.; Goga, T.; Harding, K.G. Review: The availability of life-cycle studies in Sweden. Int. J. Life Cycle Assess. 2019, 24, 6-11. [CrossRef]

18. Life Cycle Assessment Theory and Practice; Springer: Berlin/Heidelberg, Germany, 2018.

19. IEA. Available online: https:/ /www.iea.org/data-and-statistics?country=WEOAFRICA\&fuel=Energy $\% 20$ supply\&indicator= ElecGenByFuel (accessed on 31 December 2020).

20. Ghazi, M.; Quaranta, G.; Duplay, J.; Hadjamor, R.; Khodja, M.; Amar, H.A.; Kessaissia, Z. Life-Cycle Impact Assessment of oil drilling mud system in Algerian arid area. Resour. Conserv. Recycl. 2011, 55, 1222-1231. [CrossRef]

21. Messaoud-Boureghda, M.Z.; Fegas, R.; Louhab, K. Study of the Environmental Impacts of Urban Wastewater Recycling (Case of Boumerdes-Algeria) by the Life Cycle Assessment Method. Asian J. Chem. 2012, 24, 339.

22. Mohamed-Zine, M.; Hamouche, A.; Krim, L. The study of potable water treatment process in Algeria (boudouaou station) -by the application of life cycle assessment (LCA). J. Environ. Health Sci. Eng. 2013, 11, 37. [CrossRef] [PubMed]

23. Boughrara, S.; Chedri, M.; Louhab, K. Evaluation of Environmental Impact of Cement Production in Algeria Using Life Cycle Assessment. ILCPA 2015, 45, 79-84. [CrossRef]

24. Makhlouf, A.; Serradj, T.; Cheniti, H. Life cycle impact assessment of ammonia production in Algeria: A comparison with previous studies. Environ. Impact Assess. Rev. 2015, 50, 35-41. [CrossRef]

25. Mohamed-Zine, M.B.; Ali, L.; Hamouche, A. Comparison of treatment methods for the assessment of environmental impacts of drilling muds by the LCA approach. J. Environ. Waste Manag. 2016, 3, 108-115.

26. Lourguioui, H.; Brigolin, D.; Boulahdid, M.; Pastres, R. A perspective for reducing environmental impacts of mussel culture in Algeria. Int. J. Life Cycle Assess. 2017, 22, 1266-1277. [CrossRef]

27. Kaoula, D.; Bouchair, A. Evaluation of environmental impacts of hotel buildings having different envelopes using a life cycle analysis approach. Indoor Built Environ. 2018, 27, 561-580. [CrossRef]

28. Amouri, M.; Mohellebi, F.; Zaïd, T.A.; Aziza, M. Sustainability assessment of Ricinus communis biodiesel using LCA Approach. Clean Technol. Environ. Policy 2017, 19,749-760. [CrossRef]

29. Deriche, M.A.; Hafaifa, A.; Tahri, A.; Mohammedi, K.; Tahri, F. Energy and environmental performance analysis of grid-connected photovoltaic systems under similar outdoor conditions in the Saharan environment. Diagnostyka 2020, 21, 13-23. [CrossRef]

30. Perrin, A.; Basset-Mens, C.; Huat, J.; Yehouessi, W. High environmental risk and low yield of urban tomato gardens in Benin. Agron Sustain. Dev. 2015, 35, 305-315. [CrossRef] 
31. Perrin, A.; Basset-Mens, C.; Huat, J.; Gabrielle, B. The variability of field emissions is critical to assessing the environmental impacts of vegetables: A Benin case-study. J. Clean. Prod. 2017, 153, 104-113. [CrossRef]

32. Amante-García, B.; López Grimau, V.; Canals Casals, L. LCA of different energy sources for a water purification plant in Burkina Fasso. DWT 2017, 76, 375-381. [CrossRef]

33. Baumert, S.; Khamzina, A.; Vlek, P.L. Greenhouse gas and energy balance of Jatropha biofuel production systems of Burkina Faso. Energy Sustain. Dev. 2018, 42, 14-23. [CrossRef]

34. Olmedo-Torre, N.; Canals Casals, L.; Amante García, B. Sustainable design of a thermosolar electricity generation power plant in Burkina Faso. J. Environ. Manag. 2018, 226, 428-436. [CrossRef] [PubMed]

35. Achten, W.M.J.; Vandenbempt, P.; Almeida, J.; Mathijs, E.; Muys, B. Life Cycle Assessment of a Palm Oil System with Simultaneous Production of Biodiesel and Cooking Oil in Cameroon. Environ. Sci. Technol. 2010, 44, 4809-4815. [CrossRef]

36. Mpele, M.; Elime Bouboama, A.; Ayina Ohandja, L.M.; Madjadoumbaye, J. Life cycle assessment of the overall energy consumption of a road construction project and its management in Cameroon. Agric. Eng. Int. Cigr J. 2010, 12, 63-73.

37. Efole Ewoukem, T.; Aubin, J.; Mikolasek, O.; Corson, M.; Tomedi Eyango, M.; Tchoumboue, J. Environmental impacts of farms integrating aquaculture and agriculture in Cameroon. J. Clean. Prod. 2012, 28, 208-214. [CrossRef]

38. Elime Bouboama, A.; Mamba, M.; Tsimi, N.I. Life Cycle Assessment of Domestic Wastewater in a Neighborhood with Spontaneous Housing-A Case Study of Bonamoussadi, Yaoundé-Cameroon. Available online: http:/ /www.aascit.org/journal/archive2 ?journalId=816\&paperId=4171 (accessed on 2 February 2021).

39. Vrech, A.; Ferfuia, C.; Bessong Ojong, W.; Piasentier, E.; Baldini, M. Energy and environmental sustainability of Jatropha-Biofuels Chain from nontoxic accessions in Cameroon. Environ. Prog. Sustain. Energy 2019, 38, 305-314. [CrossRef]

40. El-Sayed Mohamed Mahgoub, M.; van der Steen, N.P.; Abu-Zeid, K.; Vairavamoorthy, K. Towards sustainability in urban water: A life cycle analysis of the urban water system of Alexandria City, Egypt. J. Clean. Prod. 2010, 18, 1100-1106. [CrossRef]

41. Roushdi, M.; El-Hawary, A.; Maghoub, M. Environmental improvement of Alexandria's wastewater treatment plants using life cycle assessment approach. Glob. Nest J. 2012, 14, 450-459.

42. Ali, A.A.M.; Negm, A.; Bady, M.; Ibrahim, M.G.E. Towards an Integrated Tool to Estimate Carbon Emissions from life Cycle Assessment of Building Materials in Egypt. Available online: https://www.researchgate.net/profile/Dr_Ahmed_Ali2/publication/2693 93690_TOWARDS_AN_INTEGRATED_TOOL_TO_ESTIMATE_CARBON_EMISSIONS_FROM_LIFE_CYCLE_ASSESSMENT_ OF_BUILDING_MATERIALS_IN_EGYPT/links/548877560cf289302e30afb2.pdf (accessed on 2 February 2021).

43. Ali, A.A.M.M.; Negm, A.M.; Bady, M.F.; Ibrahim, M.G. Environmental Life Cycle Assessment of a Residential Building in Egypt: A Case Study. Procedia Technol. 2015, 19, 349-356. [CrossRef]

44. Ali, A.A.M.; Negm, A.M.; Bady, M.F.; Ibrahim, M.G.E. Moving towards an Egyptian national life cycle inventory database. Int. J. Life Cycle Assess. 2014, 19, 1551-1558. [CrossRef]

45. Bevilacqua, M.; Ciarapica, F.E.; Mazzuto, G.; Paciarotti, C. Environmental analysis of a cotton yarn supply chain. J. Clean. Prod. 2014, 82, 154-165. [CrossRef]

46. Armanuos, A.M.; Negm, A.; Tahan, A.H.M.E. Life Cycle Assessment of Diesel Fuel and Solar Pumps in Operation Stage for Rice Cultivation in Tanta, Nile Delta, Egypt. Procedia Technol. 2016, 22, 478-485. [CrossRef]

47. Fawzy, M.M.; Romagnoli, F. Environmental Life Cycle Assessment for Jatropha Biodiesel in Egypt. Energy Procedia 2016, 95, 124-131. [CrossRef]

48. Sharaan, M.; Negm, A. Life Cycle Assessment of Dredged Materials Placement Strategies: Case Study, Damietta Port, Egypt. Procedia Eng. 2017, 181, 102-108. [CrossRef]

49. Petrillo, A.; De Felice, F.; Jannelli, E.; Autorino, C.; Minutillo, M.; Lavadera, A.L. Life cycle assessment (LCA) and life cycle cost (LCC) analysis model for a stand-alone hybrid renewable energy system. Renew. Energy 2016, 95, 337-355. [CrossRef]

50. Henriksson, P.J.; Dickson, M.; Allah, A.N.; Al-Kenawy, D.; Phillips, M. Benchmarking the environmental performance of best management practice and genetic improvements in Egyptian aquaculture using life cycle assessment. Aquaculture 2017, 468, 53-59. [CrossRef]

51. Younes, M.; Huang, Y.; Hashim, I. Towards an Integrated Tool of a Life Cycle Assessment for Construction of Asphalt Pavements in Egypt. J. Earth Sci. Geotech. Eng. 2016, 6, 377-388.

52. Elkafoury, A.; Negm, A. Assessment Approach of Life Cycle of Vehicles Tyres on Egyptian Road Network. Period. Polytech. Transp. Eng. 2016, 44, 75-79. [CrossRef]

53. Yacout, D.M.M.; Soliman, N.F.; Yacout, M.M. Comparative life cycle assessment (LCA) of Tilapia in two production systems: Semi-intensive and intensive. Int. J. Life Cycle Assess. 2016, 21, 806-819. [CrossRef]

54. Yacout, D.M.M.; Abd El-Kawi, M.A.; Hassouna, M.S. Cradle to gate environmental impact assessment of acrylic fiber manufacturing. Int. J. Life Cycle Assess. 2016, 21, 326-336. [CrossRef]

55. Ali, A.A.M.; Negm, A.M.; Bady, M.F.; Ibrahim, M.G.E.; Suzuki, M. Environmental impact assessment of the Egyptian cement industry based on a life-cycle assessment approach: A comparative study between Egyptian and Swiss plants. Clean. Tech. Environ. Policy 2016, 18, 1053-1068. [CrossRef]

56. Yacout, D.M.M.; Hassouna, M.S. Identifying potential environmental impacts of waste handling strategies in textile industry. Environ. Monit Assess. 2016, 188, 445. [CrossRef] 
57. Ibrahim, M.; Ali, A.A.M. Practical Case Study for Life Cycle Assessment of the Egyptian Brick Industry: A Comparative Analysis of the Japanese Industry. Available online: https:/ / scholar.google.com/citations?user=5Ng0zOMAAAAJ\&hl=en (accessed on 2 February 2021).

58. Hassanain, E.M.; Yacout, D.M.M.; Metwally, M.A.; Hassouna, M.S. Life cycle assessment of waste strategies for used lubricating oil. Int. J. Life Cycle Assess. 2017, 22, 1232-1240. [CrossRef]

59. Awad, H.; Gar Alalm, M.; El-Etriby, H.K. Environmental and cost life cycle assessment of different alternatives for improvement of wastewater treatment plants in developing countries. Sci. Total Environ. 2019, 660, 57-68. [CrossRef]

60. Atia, N.G.; Bassily, M.A.; Elamer, A.A. Do life-cycle costing and assessment integration support decision-making towards sustainable development? J. Clean. Prod. 2020, 267, 122056. [CrossRef]

61. Morsy, K.M.; Mostafa, M.K.; Abdalla, K.Z.; Galal, M.M. Life Cycle Assessment of Upgrading Primary Wastewater Treatment Plants to Secondary Treatment Including a Circular Economy Approach. Air Soil Water Res. 2020, 13, 117862212093585. [CrossRef]

62. Patrizi, N.; Bruno, M.; Saladini, F.; Parisi, M.L.; Pulselli, R.M.; Bjerre, A.B.; Bastianoni, S. Sustainability Assessment of Biorefinery Systems Based on Two Food Residues in Africa. Front. Sustain. Food Syst. 2020, 4. [CrossRef]

63. Sahle, A.; Potting, J. Environmental life cycle assessment of Ethiopian rose cultivation. Sci. Total Environ. 2013, 443, 163-172. [CrossRef]

64. Lansche, J.; Müller, J. Life cycle assessment (LCA) of biogas versus dung combustion household cooking systems in developing countries-A case study in Ethiopia. J. Clean. Prod. 2017, 165, 828-835. [CrossRef]

65. Woldegebriel, D.; Udo, H.; Viets, T.; van der Harst, E.; Potting, J. Environmental impact of milk production across an intensification gradient in Ethiopia. Livestock Sci. 2017, 206, 28-36. [CrossRef]

66. Teffera, B.; Assefa, B.; Björklund, A.; Assefa, G. Life cycle assessment of wind farms in Ethiopia. Int. J. Life Cycle Assess. 2020, 21, 76-96.

67. Afrane, G.; Ntiamoah, A. Analysis of the life-cycle costs and environmental impacts of cooking fuels used in Ghana. Appl. Energy 2012, 98, 301-306. [CrossRef]

68. Ansah, M.K.; Chen, X.; Yang, H.; Lu, L.; Lam, P.T. An integrated life cycle assessment of different façade systems for a typical residential building in Ghana. Sustain. Cities Soc. 2020, 53, 101974. [CrossRef]

69. Bianchi, F.R.; Moreschi, L.; Gallo, M.; Vesce, E.; Del Borghi, A. Environmental analysis along the supply chain of dark, milk and white chocolate: A life cycle comparison. Int. J. Life Cycle Assess. 2020, 4. [CrossRef]

70. Eshun, J.F.; Potting, J.; Leemans, R. LCA of the timber sector in Ghana: Preliminary life cycle impact assessment (LCIA). Int. J. Life Cycle Assess. 2011, 16, 625-638. [CrossRef]

71. Afrane, G.; Ntiamoah, A. Comparative Life Cycle Assessment of Charcoal, Biogas, and Liquefied Petroleum Gas as Cooking Fuels in Ghana. J. Ind. Ecol. 2011, 15, 539-549. [CrossRef]

72. Engelbrecht, D.; Thorpe, M.; Mearns, K. The life cycle assessment of cyanide containers in Ghana. Ghana Min. J. 2012, 13, 56-66.

73. Eshun, J.F.; Potting, J.; Leemans, R. Inventory analysis of the timber industry in Ghana. Int. J. Life Cycle Assess. 2010, 15, 715-725. [CrossRef]

74. Ntiamoah, A.; Afrane, G. Environmental impacts of cocoa production and processing in Ghana: Life cycle assessment approach. J. Clean. Prod. 2008, 16, 1735-1740. [CrossRef]

75. Ndong, R.; Montrejaud-Vignoles, M.; Saint Girons, O.; Gabrielle, B.; Pirot, R.; Domergue, M.; Sablayrolles, C. Life cycle assessment of biofuels fromJatropha curcasin West Africa: A field study. GCB Bioenergy 2009, 1, 197-210. [CrossRef]

76. Sim, S.; Barry, M.; Clift, R.; Cowell, S.J. The relative importance of transport in determining an appropriate sustainability strategy for food sourcing. Int. J. Life Cycle Assess. 2007, 12, 422-431.

77. Owsianiak, M.; Lindhjem, H.; Cornelissen, G.; Hale, S.E.; Sørmo, E.; Sparrevik, M. Environmental and economic impacts of biochar production and agricultural use in six developing and middle-income countries. Sci. Total Environ. 2021, 755, 142455. [CrossRef] [PubMed]

78. Bilich, A.; Langham, K.; Geyer, R.; Goyal, L.; Hansen, J.; Krishnan, A.; Bergesen, J.; Sinha, P. Life Cycle Assessment of Solar Photovoltaic Microgrid Systems in Off-Grid Communities. Environ. Sci. Technol. 2017, 51, 1043-1052. [CrossRef] [PubMed]

79. Heller, M.C.; Walchale, A.; Heard, B.R.; Hoey, L.; Khoury, C.K.; De Haan, S.S.; Burra, D.; Duong, T.T.; Osiemo, J.; Trinh, T.H.; et al. Environmental analyses to inform transitions to sustainable diets in developing countries: Case studies for Vietnam and Kenya. Int. J. Life Cycle Assess. 2020, 25, 1183-1196. [CrossRef]

80. Carvalho, R.L.; Yadav, P.; García-López, N.; Lindgren, R.; Nyberg, G.; Diaz-Chavez, R.; Krishna Kumar Upadhyayula, V.; Boman, C.; Athanassiadis, D. Environmental Sustainability of Bioenergy Strategies in Western Kenya to Address Household Air Pollution. Energies 2020, 13, 719. [CrossRef]

81. Irhoma, A.; Su, D.; Higginson, M. Life Cycle Assessment of Libyan Crude Oil. Available online: http://irep.ntu.ac.uk/id/eprint/ $7491 /$ (accessed on 2 February 2021).

82. Al-Behadili, S.; El-Osta, W. Life Cycle Assessment of Dernah (Libya) wind farm. Renew. Energy 2015, 83, 1227-1233. [CrossRef]

83. Andrianaivo, L.; Ramasiarinoro, V.J. Life Cycle Assessment and Environmental Impact Evaluation of the Parabolic Solar Cooker SK14 in Madagascar. J. Clean Energy Technol. 2014. [CrossRef]

84. Praene, J.; Rakotoson, V. Environmental sustainability of electricity generation under insular context, An LCA-based scenario for Madagascar and Reunion island by 2050. Int. J. Eng. Res. Manag. Stud. 2017, 2, $24-42$. 
85. Taulo, J.; Sebitosi, A. Material and energy flow analysis of the Malawian tea industry. Renew. Sustain. Energy Rev. 2016, 56, 1337-1350. [CrossRef]

86. Mpakati-Gama, E.C.; Brown, A.; Sloan, B. Embodied energy and carbon analysis of urban residential buildings in Malawi. Int. J. Constr. Manag. 2016, 16, 1-12. [CrossRef]

87. Pell, R.; Wall, F.; Yan, X.; Li, J.; Zeng, X. Mineral processing simulation based-environmental life cycle assessment for rare earth project development: A case study on the Songwe Hill project. J. Environ. Manag. 2019, 249, 109353. [CrossRef] [PubMed]

88. Kalogirou, S. Thermal performance, economic and environmental life cycle analysis of thermosiphon solar water heaters. Sol. Energy 2009, 83, 39-48. [CrossRef]

89. Almeida, J.; Moonen, P.; Soto, I.; Achten, W.M.; Muys, B. Effect of farming system and yield in the life cycle assessment of Jatropha-based bioenergy in Mali. Energy Sustain. Dev. 2014, 23, 258-265. [CrossRef]

90. Roffeis, M.; Almeida, J.; Wakefield, M.; Valada, T.; Devic, E.; Koné, N.; Kenis, M.; Nacambo, S.; Fitches, E.; Koko, G. Life Cycle Inventory Analysis of Prospective Insect Based Feed Production in West Africa. Sustainability 2017, 9, 1697. [CrossRef]

91. Naughton, C.C.; Zhang, Q.; Mihelcic, J.R. Modelling energy and environmental impacts of traditional and improved shea butter production in West Africa for food security. Sci. Total Environ. 2017, 576, 284-291. [CrossRef]

92. Avadí, A.; Marcin, M.; Biard, Y.; Renou, A.; Gourlot, J.; Basset-Mens, C. Life cycle assessment of organic and conventional non-Bt cotton products from Mali. Int. J. Life Cycle Assess. 2020, 25, 678-697. [CrossRef]

93. Vázquez-Rowe, I.; Moreira, M.T.; Feijoo, G. Environmental assessment of frozen common octopus (Octopus vulgaris) captured by Spanish fishing vessels in the Mauritanian EEZ. Mar. Policy 2012, 36, 180-188. [CrossRef]

94. Martín-Consuegra Ávila, F.; Alonso Ruiz-Rivas, C.; Salas Serrano, J.; Legarra Sadaba, J.; Frutos Vázquez, B. Environmental assessment of a constructive system for living spaces made in Mauritania. Available online: https://www.irbnet.de/daten/ iconda/CIB_DC28312.pdf (accessed on 5 February 2021).

95. Ramjeawon, T. Life cycle assessment of cane-sugar on the island of mauritius. Int. J. LCA 2004, 9, 254-260. [CrossRef]

96. Mohee, R. Life Cycle Assessment technique for sound management of organic municipal solid wastes. PIE 2005, 2, 236. [CrossRef]

97. Ramjeawon, T. Life cycle assessment of electricity generation from bagasse in Mauritius. J. Clean. Prod. 2008, 16, 1727-1734. [CrossRef]

98. Foolmaun, R.K.; Ramjeawon, T. Life Cycle Assessment (LCA) of PET bottles and comparative LCA of three disposal options in Mauritius. IJEWM 2008, 2, 125. [CrossRef]

99. Unmar, G.; Mohee, R.; Rughoonundun, M. Assessing the Environmental Impacts of Municipal Solid Waste Incineration in Mauritius from a Life Cycle Perspective. Available online: https: / www.semanticscholar.org/paper / Assessing-the-environmentalimpacts-of-municipal-in-Unmar-Rughoonundun/db12311c369508646cff5abb3e28486d97c74bf6 (accessed on 2 February 2021).

100. Foolmaun, R.K.; Ramjeeawon, T. Comparative life cycle assessment and social life cycle assessment of used polyethylene terephthalate (PET) bottles in Mauritius. Int. J. Life Cycle Assess. 2013, 18, 155-171. [CrossRef]

101. Foolmaun, R.K.; Ramjeeawon, T. Disposal of post-consumer polyethylene terephthalate (PET) bottles: Comparison of five disposal alternatives in the small island state of Mauritius using a life cycle assessment tool. Environ. Technol. 2012, 33, 563-572. [CrossRef]

102. Foolmaun, R.K.; Ramjeeawon, T. Comparative life cycle assessment and life cycle costing of four disposal scenarios for used polyethylene terephthalate bottles in Mauritius. Environ. Technol. 2012, 33, 2007-2018. [CrossRef] [PubMed]

103. Brizmohun, R.; Ramjeawon, T.; Azapagic, A. Life cycle assessment of electricity generation in Mauritius. J. Clean. Prod. 2015, 106, 565-575. [CrossRef]

104. Rajcoomar, A.; Ramjeawon, T. Life cycle assessment of municipal solid waste management scenarios on the small island of Mauritius. Waste Manag. Res. 2017, 35, 313-324. [CrossRef]

105. Payen, S.; Basset-Mens, C.; Perret, S. LCA of local and imported tomato: An energy and water trade-off. J. Clean. Prod. 2015, 87, 139-148. [CrossRef]

106. Bessou, C.; Basset-Mens, C.; Latunussa, C.; Velu, A.; Heitz, H.; Vannières, H.; Caliman, J.P. LCA of perennial crops: Implications of modeling choices through two contrasted case studies. In Proceedings of the LCAfood 2014, San Francisco, CA, USA, 8-10 October 2014.

107. Basset-Mens, C.; Vannière, H.; Grasselly, D.; Heitz, H.; Braun, A.; Payen, S.; Koch, P.; Biard, Y. Environmental impacts of imported and locally grown fruits for the French market: A cradle-to-farm-gate LCA study. Fruits 2016, 71, 93-104. [CrossRef]

108. Corona, B.; Escudero, L.; Quéméré, G.; Luque-Heredia, I.; San Miguel, G. Energy and environmental life cycle assessment of a high concentration photovoltaic power plant in Morocco. Int. J. Life Cycle Assess. 2017, 22, 364-373. [CrossRef]

109. Ito, M.; Lespinats, S.; Merten, J.; Malbranche, P.; Kurokawa, K. Life cycle assessment and cost analysis of very large-scale PV systems and suitable locations in the world. Prog. Photovolt Res. Appl. 2016, 24, 159-174. [CrossRef]

110. Bessou, C.; Basset-Mens, C.; Latunussa, C.; Vélu, A.; Heitz, H.; Vannière, H.; Caliman, J.P. Partial modelling of the perennial crop cycle misleads LCA results in two contrasted case studies. Int. J. Life Cycle Assess. 2016, 21, 297-310. [CrossRef]

111. Stropnik, R.; Sekavčnik, M.; Ferriz, A.; Mori, M. Reducing environmental impacts of the ups system based on PEM fuel cell with circular economy. Energy 2018, 165, 824-835. [CrossRef]

112. Errouame Mohammed and Amrani Mahacine. The Headrest Manufacturing Industry: Evaluation The Environmental impacts. Available online: http://www.arpnjournals.org/jeas/research_papers/rp_2019/jeas_0119_7540.pdf (accessed on 2 February 2021). 
113. Herrera, I.; Rodríguez-Serrano, I.; Garrain, D.; Lechón, Y.; Oliveira, A. Sustainability assessment of a novel micro solar thermal: Biomass heat and power plant in Morocco. J. Ind. Ecol. 2020, 24, 1. [CrossRef]

114. Kouroum, L.A.E.; Bahi, L.; Bahi, A. Impact of Solar Water Heaters Systems on the Environment Case Study in Morocco. Available online: https:/ / papers.ssrn.com/sol3/papers.cfm?abstract_id=3628490 (accessed on 2 February 2021).

115. Bahi, Y.; Akhssas, A.; Bahi, A.; Driss Elhachmi, D. Environmental assessment of a wastewater treatment plant using life cycle assessment (lca) approach: Case of ain taoujdate morocco. Int. J. Adv. Res. Eng. Technol. (Ijaret) 2020, 11, 3628407.

116. Hagman, J.; Nerentorp, M.; Arvidsson, R.; Molander, S. Do biofuels require more water than do fossil fuels? Life cycle-based assessment of jatropha oil production in rural Mozambique. J. Clean. Prod. 2013, 53, 176-185. [CrossRef]

117. Porsö, C.; Mate, R.; Vinterbäck, J.; Hansson, P. Time-Dependent Climate Effects of Eucalyptus Pellets Produced in Mozambique Used Locally or for Export. Bioenerg. Res. 2016, 9, 942-954. [CrossRef]

118. Gujba, H.; Mulugetta, Y.; Azapagic, A. Environmental and economic appraisal of power generation capacity expansion plan in Nigeria. Energy Policy 2010, 38, 5636-5652. [CrossRef]

119. Bartlett, Z.; Olivares, A.; Yang, L.; Rosentrater, K.A. Economic and Environmental Analysis of Farm-Scale Biodigesters to Produce Energy for Kitchen Stove Use. Available online: https:/ / elibrary.asabe.org/abstract.asp?aid=44877 (accessed on 2 February 2021).

120. Ezema, I.C.; Olutuah, A.O.; Fagbenle, O.I. Estimating Embodied Energy in Residential Buildings in a Nigerian Context. Int. J. Appl. Eng. Res. 2015, 10, 44140-44149.

121. Ogundipe, F.O.; Jimoh, O.D. Life Cycle Assessment of Municipal Solid Waste Management in Minna, Niger State, Nigeria. Int. J. Environ. Res. 2015, 9, 1305-1314.

122. Onabanjo, T.; Di Lorenzo, G. Energy Efficiency and Environmental Life Cycle Assessment of Jatropha for Energy in Nigeria: A "Well-To-Wheel" Perspective. Available online: https://asmedigitalcollection.asme.org/ES/proceedings-abstract/ES2015/5684 0/V001T06A004/228261 (accessed on 2 February 2021).

123. Ewemoje, T.A.; Oluwaniyi, O.O. Mechanised Shea Butter Production in South-Western Nigeria Using Life Cycle Assessments (LCA) Approach from Gate-To-Gate. Available online: https://cigrjournal.org/index.php/Ejounral/article/view/3557 (accessed on 2 February 2021).

124. Abubakar Jumare, I.; Bhandari, R.; Zerga, A. Environmental Life Cycle Assessment of Grid-Integrated Hybrid Renewable Energy Systems in Northern Nigeria. Sustainability 2019, 11, 5889. [CrossRef]

125. Yuguda, T.K.; Li, Y.; Xiong, W.; Zhang, W. Life cycle assessment of options for retrofitting an existing dam to generate hydroelectricity. Int. J. Life Cycle Assess. 2020, 25, 57-72. [CrossRef]

126. Ogunjirin, O.C.; Jekayinfa, S.O.; Olaniran, J.A.; Ogunjirin, O.A. Environmental life cycle assessment of cowpea production, storage and disposal in Ilorin, Kwara State, Nigeria. Iop Conf. Ser. Earth Environ. Sci. 2020, 445, 012040. [CrossRef]

127. Olaniran, J.A.; Jekayinfa, S.O.; Adekanye, T.A. Energy consumption and environmental burden analysis of cassava tuber production in Ogbomoso southwest Nigeria. Iop Conf. Ser. Earth Environ. Sci. 2020, 445, 012062. [CrossRef]

128. Ogunlade, C.A.; Jekayinfa, S.O.; Olaniran, J.A.; Adebayo, A.O. Energy life-cycle assessment and economic analysis of sweet orange production in Nigeria. Available online: https://www.researchgate.net/publication/342452508_Energy_life-cycle_ assessment_and_economic_analysis_of_sweet_orange_production_in_Nigeria (accessed on 2 February 2021).

129. Gujba, H.; Mulugetta, Y.; Azapagic, A. Passenger transport in Nigeria: Environmental and economic analysis with policy recommendations. Energy Policy 2013, 55, 353-361. [CrossRef]

130. Jekayinfa, S.O.; Olaniran, L.A.; Sasanya, B.F. Life cycle assessment of soybeans production and processing system into soy oil using solvent extraction process. Int. J. Prod. Lifecycle Manag. 2013, 6, 311-321. [CrossRef]

131. Basset-Mens, C.; Rhino, B.; Ndereyimana, A.; Kleih, U.; Biard, Y. Eco-efficiency of tomato from Rwamagana district in Rwanda: From field constraints to statistical significance. J. Clean. Prod. 2019, 229, 420-430. [CrossRef]

132. Ziegler, F.; Emanuelsson, A.; Eichelsheim, J.L.; Flysjö, A.; Ndiaye, V.; Thrane, M. Extended Life Cycle Assessment of Southern Pink Shrimp Products Originating in Senegalese Artisanal and Industrial Fisheries for Export to Europe. J. Ind. Ecol. 2011, 15, 527-538. [CrossRef]

133. Rossi, F.; Parisi, M.L.; Maranghi, S.; Manfrida, G.; Basosi, R.; Sinicropi, A. Environmental impact analysis applied to solar pasteurization systems. J. Clean. Prod. 2019, 212, 1368-1380. [CrossRef]

134. Brent, A.C.; Rohwer, M.B.; Friedrich, E.; Blottnitz, H.V. Status of life cycle assessment and engineering research in South Africa. Int. J. LCA 2002, 7, 167-172. [CrossRef]

135. Brent, A.C.; Hietkamp, S. Comparative evaluation of Life Cycle Impact assessment methods with a South African case study. Int. J. LCA 2003, 8, 27-38. [CrossRef]

136. Friedrich, E. Life-cycle assessment as an environmental management tool in the production of potable water. Water Sci. Technol. 2002, 46, 29-36. [CrossRef]

137. Brent, A.C. A proposed lifecycle impact assessment framework for South Africa from available environmental data. S. Afr. J. Sci. 2003, 99, 115-122.

138. Landu, L.; Brent, A.C. Environmental life cycle assessment of water supply in South Africa: The Rosslyn industrial area as a case study. Water SA 2006, 32, 249-256. [CrossRef]

139. Friedrich, E.; Pillay, S.; Buckley, C.A. Environmental life cycle assessments for water treatment processes-A South African case study of an urban water cycle. Water SA 2009, 35. [CrossRef] 
140. Mashoko, L.; Mbohwa, C.; Thomas, V.M. LCA of the South African sugar industry. J. Environ. Plan. Manag. 2010, 53, $793-807$. [CrossRef]

141. Anders, S.G.A.; Han, D.; Luo, S.; Belfqih, M.; Gerber, E. Added value of Life Cycle Assessment to a Business Case Analysis of a Photovoltaic/Wind Radio Base Site Solution in South Africa. Intelec 2012, 1-7. [CrossRef]

142. Vossberg, C.; Mason-Jones, K.; Cohen, B. An energetic life cycle assessment of C\&D waste and container glass recycling in Cape Town, South Africa. Resour. Conserv. Recycl. 2014, 88, 39-49.

143. Rice, G.A.; Vosloo, P.T. A life cycle assessment of the cradle-to-gate phases of clay brick production in South Africa. Eco-Archit. $V$ Harmon. Archit. Nat. 2014, 142, 471.

144. Siracusa, V.; Ingrao, C.; Lo Giudice, A.; Mbohwa, C.; Dalla Rosa, M. Environmental assessment of a multilayer polymer bag for food packaging and preservation: An LCA approach. Food Res. Int. 2014, 62, 151-161. [CrossRef]

145. Petersen, A.; Melamu, R.; Knoetze, J.; Görgens, J. Comparison of second-generation processes for the conversion of sugarcane bagasse to liquid biofuels in terms of energy efficiency, pinch point analysis and Life Cycle Analysis. Energy Convers. Manag. 2015, 91, 292-301. [CrossRef]

146. Pryor, S.W.; Smithers, J.; Lyne, P.; van Antwerpen, R. Impact of agricultural practices on energy use and greenhouse gas emissions for South African sugarcane production. J. Clean. Prod. 2017, 141, 137-145. [CrossRef]

147. Ngwepe, L.L.; Aigbavboa, C.O.; Thwala, W.D. The Benefits of life Cycle Assessment: A Methodology for Buildings in South Africa. Available online: https://ujcontent.uj.ac.za/vital/access/manager/Repository/uj:21123?site_name=GlobalView\&f0 =bs_metadata.fulltext $\% 3 \mathrm{~A} \% 22$ false $\% 22 \& \mathrm{f1}=$ sm_creator $\% 3 \mathrm{~A} \% 22$ Aigbavboa $\% 2 C+C .0 . \% 22$ (accessed on 2 February 2021).

148. Naicker, V.; Cohen, B. A life cycle assessment of e-books and printed books in South Africa. J. Energy S. Afr. 2016, $27,68-77$. [CrossRef]

149. Daful, A.G.; Haigh, K.; Vaskan, P.; Görgens, J.F. Environmental impact assessment of lignocellulosic lactic acid production: Integrated with existing sugar mills. Food Bioprod. Process. 2016, 99, 58-70. [CrossRef]

150. Crafford, P.L.; Blumentritt, M.; Wessels, C.B. The potential of South African timber products to reduce the environmental impact of buildings. S. Afr. J. Sci. 2017, 113, 1-8. [CrossRef]

151. The Environmental Mitigation Potential of Photovoltaic-Powered Irrigation in the Production of South African Maize. Sustainability 2017, 9, 1772. [CrossRef]

152. Russo, V.; von Blottnitz, H. Potentialities of biogas installation in South African meat value chain for environmental impacts reduction. J. Clean. Prod. 2017, 153, 465-473. [CrossRef]

153. Farzad, S.; Mandegari, M.A.; Guo, M.; Haigh, K.F.; Shah, N.; Görgens, J.F. Multi-product biorefineries from lignocelluloses: A pathway to revitalisation of the sugar industry? Biotechnol. Biofuels 2017, 10, 87. [CrossRef] [PubMed]

154. Mandegari, M.A.; Farzad, S.; van Rensburg, E.; Görgens, J.F. Multi-criteria analysis of a biorefinery for co-production of lactic acid and ethanol from sugarcane lignocellulose. Biofuels Bioprod. Bioref. 2017, 11, 971-990. [CrossRef]

155. Ali Mandegari, M.; Farzad, S.; Görgens, J.F. Economic and environmental assessment of cellulosic ethanol production scenarios annexed to a typical sugar mill. Bioresour. Technol. 2017, 224, 314-326. [CrossRef]

156. Farzad, S.; Mandegari, M.A.; Görgens, J.F. Integrated techno-economic and environmental analysis of butadiene production from biomass. Bioresour. Technol. 2017, 239, 37-48. [CrossRef] [PubMed]

157. Papadaki, D.; Foteinis, S.; Mhlongo, G.; Nkosi, S.; Motaung, D.; Ray, S.; Tsoutsos, T.; Kiriakidis, G. Life cycle assessment of facile microwave-assisted zinc oxide ( $\mathrm{ZnO})$ nanostructures. Sci. Total Environ. 2017, 586, 566-575. [CrossRef]

158. Madushela, N. Process Evaluation of a Domestic Biogas Digester. Procedia Manuf. 2017, 7, 111-117. [CrossRef]

159. Agwa-Ejon, J.F.; Pradhan, A. Life cycle impact assessment of artisanal sandstone mining on the environment and health of mine workers. Environ. Impact Assess. Rev. 2018, 72, 71-78. [CrossRef]

160. Masindi, V.; Chatzisymeon, E.; Kortidis, I.; Foteinis, S. Assessing the sustainability of acid mine drainage (AMD) treatment in South Africa. Sci. Total Environ. 2018, 635, 793-802. [CrossRef]

161. Anastasopoulou, A.; Kolios, A.; Somorin, T.; Sowale, A.; Jiang, Y.; Fidalgo, B.; Parker, A.; Williams, L.; Collins, M.; McAdam, E.; et al. Conceptual environmental impact assessment of a novel self-sustained sanitation system incorporating a quantitative microbial risk assessment approach. Sci. Total Environ. 2018, 639, 657-672. [CrossRef]

162. Pradhan, A.; Mbohwa, C. Life Cycle Assessment of Soybean Biodiesel Production in South Africa: A Preliminary Assessment. In Proceedings of the 2017 International Renewable and Sustainable Energy Conference (IRSEC), Tangier, Morocco, 4-7 December 2017; pp. 1-4. [CrossRef]

163. Pradhan, A.; Mbohwa, C. Development of Life Cycle Inventory (LCI) for Sugarcane Ethanol Production in South Africa. In Proceedings of the 2017 International Renewable and Sustainable Energy Conference (IRSEC), Tangier, Morocco, 4-7 December 2017; pp. 1-4. [CrossRef]

164. Goga, T.; Friedrich, E.; Buckley, C. Environmental life cycle assessment for potable water production-a case study of seawater desalination and mine-water reclamation in South Africa. Water SA 2019, 45, 700-709. [CrossRef]

165. Kwofie, T.E.; Aigbavboa, C.O.; Thwala, W.D. Measures to improve the adoption of life cycle assessment in the South African construction industry. JEDT 2019, 18, 480-494. [CrossRef]

166. Dunmade, I.; Madushele, N.; Adedeji, P.A.; Akinlabi, E.T. A streamlined life cycle assessment of a coal-fired power plant: The South African case study. Environ. Sci. Pollut. Res. 2019, 26, 18484-18492. [CrossRef] 
167. Chitaka, T.Y.; Russo, V.; von Blottnitz, H. In pursuit of environmentally friendly straws: A comparative life cycle assessment of five straw material options in South Africa. Int. J. Life Cycle Assess. 2020, 25, 1818-1832. [CrossRef]

168. Mavhungu, A.; Foteinis, S.; Mbaya, R.; Masindi, V.; Kortidis, I.; Mpenyana-Monyatsi, L. Environmental sustainability of municipal wastewater treatment through struvite precipitation: Influence of operational parameters. J. Clean. Prod. 2020. [CrossRef]

169. Van der Laan, M.; Jumman, A.; Perret, S.R. Environmental Benefits of Improved Water and Nitrogen Management in Irrigated Sugar Cane: A Combined Crop Modelling and Life Cycle Assessment Approach. Irrig. Drain. 2015, 64, 241-252. [CrossRef]

170. Devers, L.; Kleynhans, T.; Mathijs, E. Comparative life cycle assessment of Flemish and Western Cape pork production. Agrekon 2012, 51, 105-128. [CrossRef]

171. Fernández-Torres, M.; Randall, D.; Melamu, R.; von Blottnitz, H. A comparative life cycle assessment of eutectic freeze crystallisation and evaporative crystallisation for the treatment of saline wastewater. Desalination 2012, 306, 17-23. [CrossRef]

172. Ras, C.; Von Blottnitz, H. A comparative life cycle assessment of process water treatment technologies at the Secunda industrial complex, South Africa. Water SA 2012, 38, 549-554. [CrossRef]

173. Stephenson, A.L.; von Blottnitz, H.; Brent, A.C.; Dennis, J.S.; Scott, S.A. Global Warming Potential and Fossil-Energy Requirements of Biodiesel Production Scenarios in South Africa. Energy Fuels 2010, 24, 2489-2499. [CrossRef]

174. Brent, A.; Sigamoney, R.; Von Blottnitz, H.; Hietkamp, S. Life cycle inventories to assess value chains in the South African biofuels industry. J. Energy S. Afr. 2010, 21, 15-25. [CrossRef]

175. Pillay, S.D.; Friedrich, E.; Buckley, C.A. Life cycle assessment of an industrial water recycling plant. Water Sci. Technol. 2002, 46, 55-62. [CrossRef]

176. Manyele, S.V. Lifecycle assessment of biofuel production from wood pyrolysis technology. Educ. Res. Rev. 2007, 2, 141-150.

177. Felix, M.; Gheewala, S.H. Environmental assessment of electricity production in Tanzania. Energy Sustain. Dev. $2012,16,439-447$. [CrossRef]

178. Eshton, B.; Katima, J.H.; Kituyi, E. Greenhouse gas emissions and energy balances of jatropha biodiesel as an alternative fuel in Tanzania. Biomass Bioenergy 2013, 58, 95-103. [CrossRef]

179. Felix, M.; Gheewala, S.H. Environmental toxicity potential from electricity generation in Tanzania. Int. J. Life Cycle Assess. 2014, 19, 1424-1432. [CrossRef]

180. Plassmann, K.; Brentrup, F.; Lammel, J. Trade-offs between agricultural product carbon footprints and land use: A case study from Tanzania. Available online: https:/ / www.researchgate.net/profile/Katharina_Plassmann (accessed on 2 February 2021).

181. Felix, M. Status update on LCA studies and networking in Tanzania. Int. J. Life Cycle Assess. 2016, 21, 1825-1830. [CrossRef]

182. Tsuchiya, Y.; Swai, T.A.; Goto, F. Energy payback time analysis and return on investment of off-grid photovoltaic systems in rural areas of Tanzania. Sustain. Energy Technol. Assess. 2020, 42, 100887.

183. Hadj Amor, R.; Quaranta, G.; Gueddari, F.; Million, D.; Clauer, N. The life cycle impact assessment applied to a coastal lagoon: The case of the Slimane lagoon (Tunisia) by the study of seasonal variations of the aquatic eutrophication potential. Environ. Geol. 2008, 54, 1103-1110. [CrossRef]

184. Jerbi, M.; Aubin, J.; Garnaoui, K.; Achour, L.; Kacem, A. Life cycle assessment (LCA) of two rearing techniques of sea bass (Dicentrarchus labrax). Aquac. Eng. 2012, 46, 1-9. [CrossRef]

185. Fersi, S. Energy analysis and potentials of biodiesel production from Jatropha Curcas in Tunisia. Int. J. Glob. Energy Issues 2012, 35, 441-455. [CrossRef]

186. Hjaila, K.; Baccar, R.; Sarrà, M.; Gasol, C.; Blánquez, P. Environmental impact associated with activated carbon preparation from olive-waste cake via life cycle assessment. J. Environ. Manag. 2013, 130, 242-247. [CrossRef] [PubMed]

187. Pradeleix, L.; Roux, P.; Bouarfa, S.; Jaouani, B.; Lili-Chabaane, Z.; Bellon-Maurel, V. Environmental Impacts of Contrasted Groundwater Pumping Systems Assessed by Life Cycle Assessment Methodology: Contribution to the Water-Energy Nexus Study. Irrig. Drain. 2015, 64, 124-138. [CrossRef]

188. Ben Jaballah, H.J.; ben Ammar, F. Life Cycle Assessment impact of fraking shale gas in Tunisia. In Proceedings of the IREC2015 The Sixth International Renewable Energy Congress, Sousse, Tunisia, 24-26 March 2015. [CrossRef]

189. Ibidhi, R.; Hoekstra, A.Y.; Gerbens-Leenes, P.; Chouchane, H. Water, land and carbon footprints of sheep and chicken meat produced in Tunisia under different farming systems. Ecol. Indic. 2017, 77, 304-313. [CrossRef]

190. Abdou, K.; Ben Rais Lasram, F.; Romdhane, M.S.; Le Loc'h, F.; Aubin, J. Rearing performances and environmental assessment of sea cage farming in Tunisia using life cycle assessment (LCA) combined with PCA and HCPC. Int. J. Life Cycle Assess. 2018, 23, 1049-1062. [CrossRef]

191. Abdou, K.; Aubin, J.; Romdhane, M.S.; Le Loc'h, F.; Lasram, F.B.R. Environmental assessment of seabass (Dicentrarchus labrax) and seabream (Sparus aurata) farming from a life cycle perspective: A case study of a Tunisian aquaculture farm. Aquaculture 2017, 471, 204-212. [CrossRef]

192. Mami, M.; Jeday, M.R.; Hajjaji, N. Life Cycle Assessment of Sulfuric Acid Production System in Tunisia. Available online: https:/ /link.springer.com/chapter/10.1007\%2F978-3-319-70548-4_148 (accessed on 2 February 2021).

193. Maaoui, M.; Boukchina, R.; Hajjaji, N. LCA and Cherry Tomato Production in the South of Tunisia. Available online: https: / /link.springer.com/chapter/10.1007/978-3-319-70548-4_319 (accessed on 2 February 2021).

194. Abdou, K.; Gascuel, D.; Aubin, J.; Romdhane, M.S.; Ben Rais Lasram, F.; Le Loc'h, F. Environmental life cycle assessment of seafood production: A case study of trawler catches in Tunisia. Sci. Total Environ. 2018, 610-611, 298-307. 
195. Jouini, M.; Burte, J.; Biard, Y.; Benaissa, N.; Amara, H.; Sinfort, C. A framework for coupling a participatory approach and life cycle assessment for public decision-making in rural territory management. Sci. Total Environ. 2019, 655, 1017-1027. [CrossRef]

196. Pradeleix, L.; Bouarfa, S.; Bellon-Maurel, V.; Roux, P. Assessing Environmental Impacts of Groundwater Irrigation Using the Life Cycle Assessment Method: Application to a Tunisian Arid Region. Irrig. Drain. 2020, 69, 117-125. [CrossRef]

197. Maaoui, M.; Boukchina, R.; Hajjaji, N. Environmental life cycle assessment of Mediterranean tomato: Case study of a Tunisian soilless geothermal multi-tunnel greenhouse. Environ. Dev. Sustain. 2020. [CrossRef]

198. Herrera, I.; Rodríguez-Serrano, I.; Lechón, Y.; Oliveira, A.; Krüger, D.; Bouden, C. Sustainability assessment of a hybrid CSP/biomass. Results of a prototype plant in Tunisia. Sustain. Energy Technol. Assess. 2020, 42, 100862.

199. Banacloche, S.; Herrera, I.; Lechón, Y. Towards energy transition in Tunisia: Sustainability assessment of a hybrid concentrated solar power and biomass plant. Sci. Total Environ. 2020, 744, 140729. [CrossRef] [PubMed]

200. Ben Abdallah, S.; Elfkih, S.; Suárez-Rey, E.M.; Parra-López, C.; Romero-Gámez, M. Evaluation of the environmental sustainability in the olive growing systems in Tunisia. J. Clean. Prod. 2020, 282, 124526. [CrossRef]

201. Abdou, K.; Le Loc'h, F.; Gascuel, D.; Romdhane, M.S.; Aubin, J.; Ben Rais Lasram, F. Combining ecosystem indicators and life cycle assessment for environmental assessment of demersal trawling in Tunisia. Int. J. Life Cycle Assess. 2020, 25, 105-119. [CrossRef]

202. Musaazi, M.K.; Mechtenberg, A.R.; Nakibuule, J.; Sensenig, R.; Miyingo, E.; Makanda, J.V.; Hakimian, A.; Eckelman, M.J. Quantification of social equity in life cycle assessment for increased sustainable production of sanitary products in Uganda. $J$. Clean. Prod. 2015, 96, 569-579. [CrossRef]

203. Oyoo, R.; Leemans, R.; Mol, A.P. Comparison of environmental performance for different waste management scenarios in East Africa: The case of Kampala City, Uganda. Habitat. Int. 2014, 44, 349-357. [CrossRef]

204. Ekeh, O.; Fangmeier, A.; Müller, J. Quantifying greenhouse gases from the production, transportation and utilization of charcoal in developing countries: A case study of Kampala, Uganda. Int. J. Life Cycle Assess. 2014, 19, 1643-1652. [CrossRef]

205. Prouty, C.; Zhang, Q. How do people's perceptions of water quality influence the life cycle environmental impacts of drinking water in Uganda? Resour. Conserv. Recycl. 2016, 109, 24-33. [CrossRef]

206. Komakech, A.; Zurbrügg, C.; Miito, G.; Wanyama, J.; Vinnerås, B. Environmental impact from vermicomposting of organic waste in Kampala, Uganda. J. Environ. Manag. 2016, 181, 395-402. [CrossRef]

207. Mfitumukiza, D.; Nambasa, H.; Walakira, P. Life cycle assessment of products from agro-based companies in Uganda. Int. J. Life Cycle Assess. 2019, 24, 1925-1936. [CrossRef]

208. Sparrevik, M.; Field, J.L.; Martinsen, V.; Breedveld, G.D.; Cornelissen, G. Life Cycle Assessment to Evaluate the Environmental Impact of Biochar Implementation in Conservation Agriculture in Zambia. Environ. Sci. Technol. 2013, 47, 1206-1215. [CrossRef]

209. Smebye, A.B.; Sparrevik, M.; Schmidt, H.P.; Cornelissen, G. Life-cycle assessment of biochar production systems in tropical rural areas: Comparing flame curtain kilns to other production methods. Biomass Bioenergy 2017, 101, 35-43. [CrossRef]

210. Mbohwa, C.; Manjera, G. An Environmental Assessment of the Life Cycle of the Plastic Carrier Bag in Zimbabwe. AMR 2007, 18-19, 501-508. [CrossRef]

211. Mbohwa, C.T.; Mashoko, L. Application of Life Cycle Assessment in the Zimbabwean Pulp and Paper industry. Available online: http:/ / www.lcm2007.ethz.ch/paper/Mbohwa.pdf (accessed on 2 February 2021).

212. Mbohwa, C.; Ganyo, B. Using Life Cycle Assessment to Assess and Identify Improvements of the Environmental Impacts of the Vehicle Leaf Spring. Available online: https://ujcontent.uj.ac.za/vital/access/manager/Repository/uj: 5174? site_name=GlobalView\&view=null\&f0=sm_creator $\% 3 \mathrm{~A} \% 22 \mathrm{Mbohwa} \% 2 \mathrm{C}+\mathrm{Charles} \% 22 \&$ sort=ss_dateNormalized $\% 2 \mathrm{~F}$ (accessed on 2 February 2021).

213. Mbohwa, C.; Moyo, S. Life Cycle Assessment of the Cement Industry in Zimbabwe. Available online: https:/ /ujcontent.uj.ac. $\mathrm{za} /$ vital/access / manager / Repository / uj:5183?site_name=GlobalView\&view=null\&f0=sm_identifier $\% 3 \mathrm{~A} \% 22$ uj $\% 3 \mathrm{~A} 5183 \% 22$ \&sort=ss_dateNormalized\%2F (accessed on 2 February 2021).

214. Gudekeya, L.; Mbohwa, C. Life Cycle Assessment of Steel Balls. Available online: https://ieeexplore.ieee.org/document/7093841 (accessed on 2 February 2021).

215. Nhubu, T.; Muzenda, E. Determination of the Least Impactful Municipal Solid Waste Management Option in Harare, Zimbabwe. Processes 2019, 7, 785. [CrossRef]

216. Nhubu, T.; Muzenda, E.; Mbohwa, C.; Agbenyeku, E.O.M. Comparative assessment of compositing and anaerobic digestion of municipal biodegradable waste in Harare, Zimbabwe. Environ. Prog. Sustain. Energy 2020, 39, e13376. [CrossRef]

217. Wernet, G.; Bauer, C.; Steubing, B.; Reinhard, J.; Moreno-Ruiz, E.; Weidema, B. The ecoinvent database version 3 (part I): Overview and methodology. Int. J. Life Cycle Assess. 2016, 21, 1218-1230. [CrossRef]

218. Life Cycle Initiative. Available online: https:/ / www.lifecycleinitiative.org/applying-lca/lca-databases-map/ (accessed on 31 December 2020).

219. Bulle, C.; Margni, M.; Patouillard, L.; Boulay, A.; Bourgault, G.; De Bruille, V.; Cao, V.; Hauschild, M.; Henderson, A.; Humbert, S.; et al. IMPACT World+: A globally regionalized life cycle impact assessment method. Int. J. Life Cycle Assess. 2019, 24, 1653-1674. [CrossRef]

220. Inaba, A.; Itsubo, N. Preface. Int. J. Life Cycle Assess. 2018, 23, 2271-2275. [CrossRef]

221. JRC. EDGARv5.0. Available online: https://edgar.jrc.ec.europa.eu/overview.php?v=50_GHG (accessed on 31 December 2020).

222. CIA. the World Factbook. Available online: https:/ / www.cia.gov/the-world-factbook/ (accessed on 28 January 2021). 
223. UNEP. Global Trade in Used Vehicles Report. Available online: https:/ /www.unep.org/resources/report/global-trade-usedvehicles-report (accessed on 31 December 2020).

224. Lenzen, M.; Sun, Y.; Faturay, F.; Ting, Y.; Geschke, A.; Malik, A. The carbon footprint of global tourism. Nat. Clim. Chang. 2018, 8, 522-528. [CrossRef]

225. Mekonnen, M.M.; Hoekstra, A.Y. The green, blue and grey water footprint of crops and derived crop products. Available online: https://hess.copernicus.org/articles/15/1577/2011/ (accessed on 2 February 2021).

226. WHO. Available online: https://www.who.int/data/gho/data/indicators/indicator-details/GHO/households-that-use-solidfuels-for-cooking-(-) (accessed on 31 December 2020).

227. WHO. Available online: https:/ /apps.who.int/gho/data/node.main.A995 (accessed on 31 December 2020).

228. World Bank. International Tourism, Number of Arrivals. Available online: https://data.worldbank.org/indicator/ST.INT.ARVL (accessed on 2 February 2021). 